\title{
O ANTIPLATONISMO PRÁTICO DE MAX STIRNER: APROPRIAÇÃO PESSOAL VS. EMANCIPAÇÃO HUMANA
}

\author{
José Crisóstomo de Souza ${ }^{1}$
}

\begin{abstract}
Resumo:
Stirner é melhor entendido como um crítico da Modernidade, mas sobretudo como um filósofo existencial da apropriação de ou do retorno a si mesmo, o que para ele envolve uma espécie de perspectivismo em primeiro lugar corpóreo e individual. Como jovem (anti-)hegeliano, ao lado - e concorrente - de Marx, Feuerbach e Bruno Bauer, Stirner volta-se contra a alienação de si na sociedade concebida como substância e igualmente contra o humano concebido como sua essência e medida, tarefa e vocação. Daí decorrem suas posições a favor da livre associação dos indivíduos enquanto únicos (já no interior da sociedade vigente, "tradicional"), a favor de uma rebeldia entendida como soerguimento e florescimento pessoais (ainda que eventualmente dentro de uma revolução social, coletiva, que aquele soerguimento teria necessariamente que completar), e de uma apropriação e fruição de si mesmo, que só dependeria em última análise dele próprio. O indivíduo é então agora, para si, senhor e medida de si mesmo, ainda que isso possa parecer muito pouco de um lado, ou intoleravelmente ofensivo de outro. O que Stirner chama provocativamente de egoísmo não é muito mais do que isso. Frente a seus rivais "teóricos", ele se recusa a dar a sua posição egoísta o caráter de Crítica mais verdadeira, já que todas as críticas teóricas dependeriam sempre em última análise de um dogma e de um pensamento. Mas apenas o caráter de uma atitude de espontaneidade recuperada/desenvolvida, desejante mais do que pensante, de apropriação, de criação e de autocriação pessoais.
\end{abstract}

Palavras-chave: Modernidade. Antiessencialismo. Apropriação. Crítica. Egoísmo.

\section{MAX STIRNER'S PRACTICAL ANTIPLATONISM: PERSONAL APROPRIATION VS. HUMAN EMANCIPATION}

\begin{abstract}
:
Stirner is better understood as a critic of Modernity, but also and mainly as an existential philosopher of reappropriation of and return to oneself, which for him entails a sort of perspectivism, corporeal and individual in the first place. As a Young (Anti-)Hegelian, together - and in competition - with Marx, Feuerbach and Bruno Bauer, Stirner turns himself against the alienation of oneself to society conceived as substance, and against the human conceived as one's essence and measure, task and vocation. From that there follows his positions in favor of the free association of individuals as unique beings (inside present, "traditional" society), in favor of personal rebellion understood as picking oneself up and as personal flourishing (even if inside a social, collective revolution, which that "uprising" must complete), and in favor of the appropriation and fruition of oneself, that would only depend on oneself. The individual is now, for herself, her own master and measure, even if that may seem too little, on one side, and, on the other, intolerably offensive. What Stirner calls egoism is not much more than that. Differently from his rivals, he refuses to claim for his egoist position the character of a truer Critique, since, for him, all theoretical critiques always depend on a dogma, an abstract thought. But instead he claims the character of an attitude of recovered/developed spontaneity, more "desiring" than intellectual, of personal appropriation, creation and self-creation.
\end{abstract}

Keywords: Modernity. Anti-essentialism. Appropriation. Critique. Egoism.

1 Prof. titular do Depto. de Filosofia do Programa de Pós-Graduação em Filosofia Contemporânea., UFBA. E-mail: josecrisostomodesouza@gmail.com 


\section{O ANTIPLATONISMO PRÁTICO DE MAX STIRNER...}

\section{José Crisóstomo de Souza}

No início dos tempos modernos ergue-se o Deus-Homem. Ao seu final, apenas Deus, no Deus-Homem, perecerá? O Deus-Homem poderá realmente morrer se apenas Deus nele perecer? Não se pensou nessa questão. Acreditou-se ter consumado tudo quando em nossos dias levou-se vitoriosamente até o fim a obra das Luzes, a vitória sobre Deus. Não se notou que o Homem matou Deus apenas para se tornar por sua vez o único Deus que reina nas Alturas. O Além fora de nós foi varrido, e com isso a obra colossal da filosofia foi consumada. Mas o Além entre nós tornou-se um novo Céu e nos convoca a um novo assalto aos Céus. Deus teve que dar lugar ao Homem, não a nós. Como se pode crer que o Homem-Deus morreu, se, nele, além de Deus, o Homem não tiver também morrido? Max Stirner.

Este texto é uma apresentação de Stirner e de parte do seu pensamento, ou melhor, é a apresentação de seu pensamento e de sua linguagem por uma parte de seu discurso. E por uma introdução que procura caracterizá-lo como filósofo, por seu verdadeiro perfil e por sua possível contribuição para a filosofia e a cultura do nosso tempo. Para o primeiro, selecionamos alguns de seus desenvolvimentos e temas, e os apresentamos o mais perto possível de sua formulação originária, da própria linguagem de Stirner. Para que o leitor tenha não apenas uma ideia do que ele diz, mas também a experiência do modo como diz - o que no caso de Stirner é particularmente relevante. De qualquer forma, o pensamento de Stirner, no Único e sua Propriedade, desenvolve-se como um círculo de círculos ou como uma espiral, de sorte que o conjunto de sua perspectiva comparece em cada parte desse desenvolvimento. Aqui deixamos de lado muito de sua extensa crítica "filosófico-psicológica" da moral e focamos mais de frente o jogo entre sua pegada política anti-política e sua ênfase, por contraposição, no pessoal, no privado, na construção de si. Por contraste, incluo algumas alusões ilustrativas a argumentos de seu adversário mais ferrenho e mais antípoda, Karl Marx, que se opôs a ele com a diatribe mais extensa e irada entre todas as que recebeu. Por fim, para não estender demasiado o texto, deixo aqui de dialogar explicitamente com um extenso conjunto de fontes e referências, de bibliografia secundária, que, entretanto, levo em consideração, e que podem ser encontradas nos meus livros que têm a ver com o assunto: A Questão da Individualidade, e Ascensão e Queda do Sujeito no Movimento Jovem Hegeliano. ${ }^{2}$

2 Retomo aqui vários trechos do A Questão da Individualidade, e com poucas modificações, pelas razões já referidas. Com relação às fontes primárias, elas estão assinaladas no texto pelas seguintes abreviaturas: UP para $O$ Único e Sua Propriedade, de Stirner, AC para Anti-Crítica (ou: Resenhadores de Stirner), também

\begin{tabular}{|c|c|c|c|c|}
\hline Qopista Dialectus & Ano 5 & n. 12 & Janeiro - Julho 2018 & p. $163-208$ \\
\hline
\end{tabular}




\section{O ANTIPLATONISMO PRÁTICO DE MAX STIRNER...}

José Crisóstomo de Souza

\section{Crítico da Modernidade, Filósofo da Apropriação Pessoal e de um Perspectivismo Prático-Sensível, Individual.}

Max Stirner (1806-1856) não tem bem uma doutrina política ou teoria social, nem mesmo uma filosofia de tipo tradicional. Qual então a sua contribuição à conversação da filosofia? o que ele pode ser para nós? Um filósofo menor, pouco conhecido, (anti)hegeliano de esquerda, que escreveu praticamente um só livro, O Único e Sua Propriedade (Der Einzige und sein Eigentum, 1845), além de uma coletânea e vários ensaios e resenhas. Um autor que com aquela obra e seu empenho iconoclasta causou considerável celeuma e acesa reação entre seus pares mais próximos - como Ludwig Feuerbach, Karl Marx, Bruno Bauer e Moses Hess. Isso no interior da competição jovem hegeliana pelo ateísmo mais completo, pelo radicalismo mais extremo, e pelo completo e final encontro da filosofia com a existência real, concreta, dos homens de carne e osso. Logo em seguida a esses embates, ele foi tomado por Kuno Fischer, não sem cabimento, como um sofista de nossos dias. Para mais tarde, adotado pelos anarquistas - até o presente seus mais numerosos admiradores e divulgadores - ficar conhecido principalmente como ferrenho adversário do Estado e expressão mais exagerada do individualismo anarquista, o que ainda é dizer pouco sobre ele. Antes disso, Marx, que depois associaria seu pensamento ao do anarquista Bakunin, tratou de deixá-lo marcado, na Ideologia Alemã (1845-46), para todo o público de sua enorme influência, como um tolo idealista histórico, que acreditaria que as ideias (filosóficas) sozinhas fazem a História, e que seu pensamento individual prevalece sobre a realidade e por si só dissolve o poder dos ideais alienantes sobre nós - os religiosos, tradicionais, mas também os ideológicos, modernos.

O renascimento e o alargamento de influência de Stirner, porém, deram-se mesmo foi com a difusão da obra de Nietzsche, na virada do séc. XIX para o séc. XX, o autor do Único aparecendo então como um precursor do filósofo do Crepúsculo dos Ídolos, talvez até uma influência sobre ele, em todo caso um proto-Nietzsche anti-hierárquico e

de Stirner, IA para A Ideologia Alemã, de Marx e Engels, SF para A Sagrada Família, também de Marx e Engels, MEF para Manuscritos Econômicos e Filosóficos, de Marx, e CFH para "Contribuição à Crítica da Filosofia de Hegel", de Ludwig Feuerbach, UF para Os Últimos Filósofos, de Moses Hess. Para $O$ Único me vali da edição francesa de Robert Réclaire (Paris: Stock et Plus, 1978) e simultaneamente da edição alemã da Philip Reclam (Stuttgart, 1972) cuja paginação assinalo com " $r$ ". Para A Ideologia Alemã, recorri à edição francesa de Gilbert Badia (Paris: Éditions Sociales, 1968) e à edição alemã da Dietz Verlag (Marx \& Engels Werke, v.3, Berlin, 1958), cuja paginação indico por "d".

\begin{tabular}{|l|l|l|l|l|}
\hline Gevista Dialectus & Ano 5 & n. 12 & Janeiro - Julho 2018 & p. 163-208 \\
\hline
\end{tabular}




\section{O ANTIPLATONISMO PRÁTICO DE MAX STIRNER... José Crisóstomo de Souza}

libertino, imoralista e defensor da irrestrita soberania do eu enquanto fundamentalmente corpo, pulsão, vontade, fruição, criação. E aqui já nos aproximamos de uma caracterização mais fiel do que realmente pode ser Stirner, que finalmente, no meio do século passado, por seu anti-essencialismo e anti-fundacionismo com respeito ao homem e aos ideais morais, e por seu indivíduo como nada criador, foi entendido como um antecipador do existencialismo sartreano em particular, e do existencialismo contemporâneo em geral, que teria assim em Stirner e Kierkegaard os precursores no séc. XIX, respectivamente de suas vertentes ateísta e cristã. Contanto que seja ressalvado que o autor do Único não é um humanista nem um filósofo da consciência nadificadora, mas do corpo fruidor, da vontade caprichosa, da singularidade soberana livre-apropriadora.

Para além das comparações com assemelhados, no entanto, Stirner é antes de mais nada um crítico da Modernidade, da cultura, de seus grandes ideais e suas grandes ideologias. De certo modo um pós-moderno avant-la-lettre, um crítico do "homem", l'homme, do Esclarecimento racionalista-universalista, e dos artigos de fé que o acompanham. Um crítico possivelmente melhor, de melhores consequências, e com certeza mais original, do que seus sucessores anti-humanistas, os desconstrucionistas franceses nossos contemporâneos. Alguns dos quais, como Deleuze e Derrida, não puderam deixar de dele tomar conhecimento, fazer uso e de the prestar reconhecimento, coisa que outros, como Foucault e Lyotard, também deveriam ter feito. Eu até diria que o anti-hegelianismo e anti-humanismo franceses, anarco-esquerdistas, teriam escolhido melhor em pôr-se abertamente na esteira de Stirner, o desinflado, irônico, não aristocrático, anti-hierárquico filósofo do homem comum, vulgar, da finitude e da diferença singular de qualquer um, com seu apelo relaxado ainda que apimentado por uma dose de fanfarronice (moderada, se comparada com a de Nietzsche) e por certo empenho em epater le bourgeois. Do que em filiar-se, paradoxalmente, aos filosoficamente mais pretenciosos e politicamente mais complicados Heidegger e Nietzsche, muito pouco de esquerda e nada anarquistas. O primeiro com sua comprometedora pars pudenda ao menos biográfica, e o segundo com uma complicada pars pudenda doutrinária, hierárquico-racialista, ambos então, em razão disso, forçosa e forçadamente maquiados por aqueles pós-modernos como gente de esquerda - tratamento que Stirner dispensaria.

\begin{tabular}{|c|c|c|c|c|}
\hline Qevista Dialectus & Ano 5 & n. 12 & Janeiro - Julho 2018 & p. $163-208$ \\
\hline
\end{tabular}




\section{O ANTIPLATONISMO PRÁTICO DE MAX STIRNER... José Crisóstomo de Souza}

O autor de O Único e sua Propriedade pode assim ser tomado como um dos filósofos, antifilósofos, nossos contemporâneos, do proclamado fim da Filosofia, mas um que aparentemente não trata de preservar para seu discurso pós-filosófico (ou pósmetafísico) um lugar superior, em última análise crítico-transcendental, equivalente ao da filosofia tradicional ou até mais elevado, por uma pretensão que eu chamaria de epocal como no caso de Nietzsche e Heidegger, ou mesmo Foucault e Derrida. Stirner é um pensador sem pedestal, um filósofo do fim das pretensões infladas da filosofia, das presunções infladas do pensamento em geral e da teoria em particular, do fim do que hoje chamamos de logocentrismo, mas também da ambição de um superior e destacado lugar para o intelectual crítico. Nas suas mãos, a filosofia vira apenas um discurso prático, retórico, persuasivo, coloquial (algo como em Montaigne, por ex.), aforístico, irônico, na primeira pessoa, e, bem entendido, nada retumbante - um discurso terapêutico. Para ele, não é o Pensamento nem a Teoria - "Crítica", "Alemã", "Francesa" - que desalienam, salvam, libertam ou emancipam. Mas o corpo, a vontade caprichosa, o engenho ou qualquer recurso que se tenha, que para isso funcione. Com efeito, na opinião de Stirner, um dar de ombros, um salto, um berro, uma imprecação, a própria alegria, podem ter igual ou melhor efeito do que uma longa crítica de ideias alegadamente opressivas e alienantes, a partir de olhar teoricamente superior. Mesmo que, para os viciados em livros e os hipertrofiados em pensamento, como os colegas filósofos e o público culto em geral, sofisticado, bempensante, de pretensões intelectuais, um livro como $O$ Único e Sua Propriedade possa ser útil, com seu tutear corrosivo, persuasivo, irônico. Um livro com um vocabulário que transforma demonstração e teoria em narrativa, dramatização, que traduz problemas teóricos em atitudes e consequências práticas, e aplica a todo pensamento grandioso e toda grande ideia teórica a navalha de Ockham da referência a si, ao uso e ao interesse próprio.

Max Stirner é um dos poucos filósofos que conheço que de modo explícito torna contingente - como seu e nada final - o ponto de vista filosófico que desenvolve e a narrativa biográfico e histórica que oferece, que teriam a ver em primeiro lugar com seu próprio desenvolvimento e experiência, de um filósofo que faz ironia consigo mesmo (Nietzsche chegue perto disso: “Talvez eu seja um bufão...”). Com efeito, para a narrativa triádica oferecida no Único, aparentemente uma paródia de ontogênese-filogênese à la filosofia alemã do séc. XIX, a criança ou o antigo é "realista", dominada pelo mundo, pelas

\begin{tabular}{|l|l|l|l|l|}
\hline Qevista Dialectus & Ano 5 & n. 12 & Janeiro - Julho 2018 & p. 163-208 \\
\hline
\end{tabular}




\section{O ANTIPLATONISMO PRÁTICO DE MAX STIRNER...}

José Crisóstomo de Souza

coisas, os objetos, a sociedade, os costumes, a família. O jovem, ou o moderno, ao contrário, é "idealista"; liberto do peso daquelas, é agora em vez disso dominado pelo pensamento, pelo espírito, por conceitos hipostasiados, grandes ideias e grandes causas, acabando por duplicar o mundo em aparente (o mundo empírico) e verdadeiro (o mundo espiritual, ideal, conceitual, teórico). Já como adulto (digamos, pós-moderno), eu, conclui Stirner, não sou mais nem uma coisa nem outra, embora trate de pôr a meu serviço e bom uso tanto coisas, que não rejeito, quanto pensamentos, que, uma vez apropriados por mim, tampouco desprezo. Sem, porém, submeter-me nem àquelas nem a esses, nem ao Mundo absolutizado nem ao Espírito ou qualquer outra coisa tornada transcendente, sagrada. Agora finalmente me oriento por e para mim mesmo. Mas, e o velho, pergunta ao final nosso biográfico filósofo destranscendentalizante? Bom, quando eu chegar lá terei tempo de pensar nisso - é sua resposta. Com o que, você, leitor, pode preferir dar um passo além ou aquém da dialética stirneriana, na direção que for de sua escolha e que tenha a ver com sua experiência do mundo, seu próprio desenvolvimento, ou seu modo de entender o da sua cultura.

Não é fácil, talvez nem seja mesmo inteiramente possível, traduzir conceitualmente o que é ou diz Stirner, porque ele não é um filósofo de teoria ou de conceito em sentido próprio. O Único e Sua Propriedade parece querer apenas ser uma fala persuasiva, irônica, terapêutica, na primeira pessoa, dirigida ao leitor como segunda pessoa, que de várias maneiras convida-o, tenha os limites e insuficiências que tiver ou suponha ter, a simplesmente "voltar para si". A não tomar outra medida para si mesmo, a não perder-se em grandes pensamentos (ideais, idola) que lhe imponham grandes obrigações universais, que se autonomizem ou levantem sobre ele próprio. Ele não cairia na tentação de oferecer, contra o Império das Ideias, do Pensamento, do Espírito (Platão, Hegel, o Cristianismo, as Ideologias), como um filósofo platonicamente anti-platônico, o próprio pensamento e a própria teoria, como Verdade, por recurso a artigos de fé da filosofia clássica, como Essência, Substância, Razão, Objetividade, ainda sobreviventes no pensamento moderno.

O autor do Único não trata de afastar essas coisas por recurso à teoria; apenas retoricamente as deprecia, questiona o alcance prático que lhes é dado, não desde um ponto de vista propriamente teórico, mas da corrosão do poder que tais “obsessões” pretendam ter sobre cada um de nós, homens inevitavelmente finitos, contingentes, particulares. Em

\begin{tabular}{|l|l|l|l|l|}
\hline Q Povista Dialectus & Ano 5 & n. 12 & Janeiro - Julho 2018 & p. 163-208 \\
\hline
\end{tabular}




\section{O ANTIPLATONISMO PRÁTICO DE MAX STIRNER... \\ José Crisóstomo de Souza}

sendo assim, Stirner não se apresenta como apenas mais um filósofo tradicional, nem como um filósofo político, nem mesmo principalmente como um adversário do Estado e das ideologias modernas do "humano" (hipostasiado), que para ele tomaram, em detrimentos dos homens de carne e osso, o lugar da religião tradicional, com novos decretos de vocação, abnegação - de alienação de si mesmo. Mas ele é antes um sedutor desplatonizante que se pretende pôr para além de ambos idealismo e realismo - por uma pegada prática, um perspectivismo anti-autoritário, um apelo ao uso, à relação e ao corpo - à nossa "naturalidade" hodierna. Para essa nova atitude, esse novo ponto de vista, o do indivíduo enquanto inevitavelmente único, ele escolhe provocativamente o nome de egoísmo - por ser um palavrão que ainda abominam tanto cristãos e reacionários como também ateus e materialistas modernos os mais radicais.

Stirner aparece-nos, assim, como um nominalista, como um anti-essencialista, um anti-substancialista, junto com antifundacionista e antilogocêntrico - mas de que tipo? Daquele em que tudo isso se combina para compor o que eu chamaria de um antiplatonismo prático-poético, voluntarista. O autor do Único se faz um crítico, mas de tipo muito particular: da verdade enquanto um poder sobre mim, que inadvertidamente entrego a um pensamento ou crença enquanto algo cujo ser seria independente de mim, seria algo válido em si e por si, fora de toda relação comigo. Crítico da objetividade enquanto essa esconderia e se sobreporia a uma relação sempre concreta, bem entendida de apropriação, uso, fruição, que eu decida ter com coisas e pensamentos. Um "crítico prático" do universal e de termos abstratos hipostasiados, um que contra esses oferece um discurso melhor seria dizer uma atitude ou conduta ou gesto - não conceitual, não epistêmico, não epistemológica. Esse próprio discurso sendo ele próprio uma forma de apropriação, de desalienação e de dessacralização do pensamento e da filosofia, contra tudo que quiser pôrse acima de mim, como transcendental ou sagrado, para além do trivialmente empírico, de um lado, e do inevitavelmente pessoal, do outro. E isso por uma descrição de suas possíveis consequências práticas "expropriadoras", em confronto com a perspectiva do indivíduocorpo, apropriador, e de seu - insignificante que seja - poder e interesse próprios, dos quais trata-se simplesmente, de um jeito ou de outro, de não abrir mão. No vocabulário de nosso anti-platônico prático, anti-autoritário, anti-opressivo, de um lado estão: relação, interesse, singularidade, apropriação, uso, fruição, criação. Do outro, por oposição, estão: realidade

\begin{tabular}{|l|l|l|l|l|}
\hline Q Revista Dialectus & Ano 5 & n. 12 & Janeiro - Julho 2018 & p. 163-208 \\
\hline
\end{tabular}




\section{O ANTIPLATONISMO PRÁTICO DE MAX STIRNER... José Crisóstomo de Souza}

em si, substância, essência, universalidade, objetividade, verdade; em termos mais práticos: auto-sujeição, abnegação, sacralização, possessão, obsessão, vocação, fixação, fanatismo. $\mathrm{Na}$ consideração do mundo e no trato com ele, tanto quando com as ideias e as pessoas, tudo resulta então entendido, em Stirner, sob a ótica do uso e da fruição, da apropriação e da livre criação (em primeiro lugar, de si mesmo, por cada um), também dentro de uma dimensão inevitável de oposição e agonismo.

Para bom entendedor filosoficamente informado, esse eu stirneriano apropriador-fruidor-criador, corpóreo, pode aparecer, razoavelmente, como uma tradução tentativamente não idealista, destranscendentalizada, desinflada, e como uma radicalização completamente anti-substancialista e antiessencialista, ambas ao mesmo tempo romântica e utilitaristamente inspiradas, do eu autoconsciência da filosofia clássica alemã. Pace Engels, então, a verdadeira Ausgang (fim, saída, resultado) dessa filosofia, uma saída mais de acordo com os novíssimos tempos e suas possibilidades. Mais do que as inclinações opostas, mais amorosas e comunitárias, que nos querem apontar, por exemplo, Marx e Feuerbach, partidários do homem como "ser-genérico". E isso, nota bene, não implica que nosso subjetivo filósofo seja avesso ao reconhecimento da materialidade do mundo e, se se quiser (ao contrário do que Marx diz dele), de sua eventual superioridade em termos de força, sobre ele, seja a do Estado ou de qualquer coisa como Mundo ou História. A autoconsciência no idealismo alemão (que inclui, assinale-se, um elemento romântico) é originariamente um Eu - com maiúscula, transcendental, universal. Que se pretende causa sui, espontaneidade, que seria eminentemente atividade, auto-atividade, negatividade, criação, autoria e autoridade.

A autoconsciência é auto-posição e posição do mundo, é relação a si, sujeito, é também dissolvedora, oposta, necessariamente agônica - é singular e, por fim, é pessoa. A autoconsciência, porém, não é um dado natural; no desdobramento que a filosofia clássica alemã dá a noção, ela é resultado de um desenvolvimento tanto ontogenético (biográfico) como também filogenético (histórico). É resultado ou construção da cultura e de certa história, ocidental, da qual o cristianismo faz parte muito relevante. Pode-se entender que é essa autoconsciência que Stirner naturaliza, desinfla, trivializa, desuniversaliza e destranscendentaliza (contra Fichte), dessubstancializa e toma como pouco assimilável a um Nós (contra Hegel, para quem, entretanto, a autoconsciência é essencialmente desejo!).

\begin{tabular}{|l|l|l|l|l|}
\hline Gevista Dialectus & Ano 5 & n. 12 & Janeiro - Julho 2018 & p. 163-208 \\
\hline
\end{tabular}




\section{O ANTIPLATONISMO PRÁTICO DE MAX STIRNER... José Crisóstomo de Souza}

Assim convertida, porém, ela de certo modo, na tradução stirneriana, às vezes aparenta ter sempre estado aí, como corpo - pulsivo, sensível, agônico, fruidor, usuário. Mas não me parece que se possa dizer por isso, com Marx, que o indivíduo egoísta stirneriano é uma "robinsonada" - um indivíduo ou eu concebido com anterior à sociedade, à cultura, à história, um universal igual, não-histórico, como para o liberalismo tradicional. Ao contrário, para Stirner, nosso estado original - estado de natureza - é justamente o dependente, gregário, a sociedade.

O ponto de vista de Stirner pode aparecer como uma radicalização românticoutilitarista das ideias de independência, liberdade, responsabilidade, autonomia, espontaneidade, criação - modernas - associadas à noção de autoconsciência. Mas numa perspectiva essencialmente naturalista, não-idealista, não-metafísica, destranscendentalizada. Seu livro apresentando-se, então, como uma descrição fenomenológica de como ficamos (para ele não tão mal assim, sem aquelas dimensões idealistas e platônicas, pelo aproveitamento pessoal, criador, dos recursos de espirito que nos trouxeram até aqui, depois de tê-las galgado. Pelo percurso cristão platônico da cultura, inicialmente emancipador com relação ao peso do mundo como dado, agora, entretanto, um percurso transformado ou consumado por uma "natural" referência a si próprio, pela assunção do nosso "ser próprio" quase que como de um princípio. No Único e sua Propriedade, a referência a esse eu único e apropriador apresenta-se como uma espécie de navalha de Ockham, contra tudo que se põe, metafisicamente, transcendentalmente, autoritariamente, para além do empírico e do sensível, do pulsivo e do relacional - do pessoal e do prático. Na prática, isso tudo em Stirner resumir-se-ia a um simples apelo a ousar querer, ousar ser, na primeira pessoa, a partir de si, como se é, enquanto finito, gênero de si mesmo, como um quem, não um que. Como quem empresta valor e mesmo ser (ser isso ou aquilo) às coisas, a partir de sua relação com elas. Reconhecendo e assumindo uma conduta que, de um jeito ou de outro, recalcada, disfarçada, contrariada, tolhida, sempre se insinuaria, mesmo que de modo contraditório, envergonhado, alienado, por interpostas mediações transcendentais - que se revelariam disfarces, fantasmas, fantasias, mascaramentos.

Entretanto, quanto a essa conversão a si, seja dito que parece haver em Stirner uma oscilação entre afirmação e negação, e pode ser que ao fim e ao cabo tenhamos que

\begin{tabular}{|l|l|l|l|l|}
\hline Qovista Dialectus & Ano 5 & n. 12 & Janeiro - Julho 2018 & p. 163-208 \\
\hline
\end{tabular}




\section{O ANTIPLATONISMO PRÁTICO DE MAX STIRNER... José Crisóstomo de Souza}

questioná-lo por certo idealismo residual. Por uma parte, o Único parece prolongar, no seu egoísmo e na sua rebeldia, a ênfase no eu-sujeito - à imagem da autoconsciência do idealismo alemão - como "essencialmente" negatividade; o ser do seu - digamos - Dasein como um ser-não, como negação. Embora, de outra parte, em outros momentos, esse eu stirneriano apareça, mais espinosanamente, como, em primeiro lugar, afirmação feliz e relaxada de si mesmo, ficando a negação, então, como derivada dessa, e não como sua primeira e mais autêntica expressão. De um lado, a conversão ao egoísmo stirneriano parece resultar em uma plena espontaneidade e em uma recuperada inocência, e, portanto, ser algo como uma atitude, digamos, cool. Sua revolução, insurreição, rebeldia seriam em primeiro lugar um levantar-se a si mesmo, não um destruir qualquer coisa, mesmo que por si resulte em mudar radicalmente o velho "feudalismo" ou "hierarquismo" ainda subsistentes na Modernidade alemã do século XIX, mesmo talvez na nossa. E seu desenvolvimento pessoal seria então um espontâneo florescer - como, na própria imagem stirneriana, o desabrochar espontâneo, sem obrigação, de uma flor. De outro lado, porém, parece às vezes que o indivíduo stirneriano só é único e só é ele mesmo enquanto negação, enquanto em permanente revolta, como quase que tendo que policiar-se o tempo todo contra qualquer descuidada adesão ou aceitação de qualquer coisa além dele. Ainda assim, de todo modo, a socialidade de Stirner não tem como mandamento excluir, por exemplo, qualquer cooperação, como se essa fosse menos natural do que seu agonismo. Mesmo uma cooperação como aquelas sugeridas por socialistas ou comunistas para uma produção econômica mais racional ou menos penosa, por exemplo. Isso, entretanto, sempre por razões práticas, não por qualquer princípio moral, sagrado, superior, por qualquer prescrição "humana" - mas sempre por interesse particular assumido. Justificada, na verdade, como meio para liberar o indivíduo e suas energias para o que ele conceber de atividade propriamente pessoal, criativa.

Afinal de contas, então, o que é Stirner e seu único, vistos por nós, por nosso interesse, e a partir do nosso tempo? Ele é parte destacada da virada prático-criadora, prático-poética, mundana, contemporânea, pós-metafísica, narrativa, da filosofia, nos nossos tempos. Mais especificamente, no seu caso, uma singular virada romântico-utilitária, pragmatista, para a esfera privada. Uma perspectiva para a tomada de coisas e ideias pelo seu valor de uso, para florescimento, fruição, criação, e, por referência a si como atividade

\begin{tabular}{|l|l|l|l|l|}
\hline Q Povista Dialectus & Ano 5 & n. 12 & Janeiro - Julho 2018 & p. 163-208 \\
\hline
\end{tabular}




\section{O ANTIPLATONISMO PRÁTICO DE MAX STIRNER... José Crisóstomo de Souza}

e autoria, por uma assunção pessoal de nossas crenças, escolhas, atitudes e condutas. Bem mais e bem melhor do que anarquista ou pós-moderno, Stirner é um proto-nietzschiano, mais moderno do que Nietzsche, anti-hierárquico, potencialmente democrático, sobretudo desinflado - finalmente um filósofo do presente. Também um imoralista, nosso antiplatônico criador poético, sensível, pinta-se aqui e ali com tons radicais juvenis - como o corruptor hiperbólico, disposto a épater le bourgeois, a exibir a mais ilimitada disposição de levar às últimas consequências, as mais bizarras, o que seria seu princípio: o egoísmo. Que seria assim, apesar de tudo, apenas mais um princípio abstrato, filosófico, em disputa com outros tantos princípios de pensamento, de seus competidores. Ambiguamente, Stirner parece até mesmo propor um novo e mais completo, agora final, assalto os Céus, do tipo do de seus concorrentes. O leitor então que decida. De todo modo, bem entendido e bem aproveitado enfim, ele, me parece, representaria antes um persuasivo apelo por uma cultura mais secularizada, des-hierarquizada, anti-autoritária, criativa, e por uma vida pessoal menos esvaziada ou pressionada por obrigações alienadas e alienantes, em primeiro lugar de auto-criação e florescimento. Em filosofia, representaria a proposta de um discurso mais despretensioso - coloquial e irônico na forma, fenomenológico e existencial no conteúdo. $\mathrm{Na}$ vida, finalmente, um convite a uma atitude mais relaxada, madura. Sem ter que para isso esperar a velhice.

\section{Stirner contra a Alienação de Si na Sociedade como Substância e no Humano como Essência e Medida}

Comecemos pelo Stirner político e social, ou melhor, pelo crítico (ou desconstrutor) da filosofia política e da teoria social, melhor dizendo, de certo idealismo metafísico nesses campos. O "liberalismo político" - começa ele, e por essa expressão pode-se entender o que se chama de emancipação política - quer os homens livres e sem senhor, pela supressão de privilégios e desigualdades de nome e nascimento, típicos do Antigo Regime. O "liberalismo social" - para ele, o reformismo social, o socialismo e o comunismo - trataria em seguida, num passo sucessivo, de abolir a diferença material de posses, entre ricos e pobres. Por fim, o "liberalismo humano" - o humanismo filosófico radical, antiparticularista, consciencialista, como o de hegelianos de esquerda como Bruno Bauer - quer "o homem" completamente livre da limitação de toda particularidade, laço

\begin{tabular}{|l|l|l|l|l|}
\hline Q Ronista Qialectus & Ano 5 & n. 12 & Janeiro - Julho 2018 & p. 163-208 \\
\hline
\end{tabular}




\section{O ANTIPLATONISMO PRÁTICO DE MAX STIRNER... \\ José Crisóstomo de Souza}

fixado, confissão religiosa ou comparável crença fixada, dogmática. Pressuposta uma essência igual e comum para os homens, aparentemente estariam assim liquidados para a Humanidade todos os tormentos irracionais - da servidão, da propriedade, da religião e demais dogmatismos e imposições injustificadas.

Na opinião de Stirner, entretanto, as coisas não seriam assim tão simples como as tomam o Iluminismo do 'l 'homme', do século XVIII, ou da Crítica hegeliana do séc. XIX. É que, separado do indivíduo "egoísta”, o "Senhor" reapareceria como o Estado e a Lei. Do mesmo modo, os bens, subtraídos ao indivíduo, teriam ainda como proprietário a Sociedade. E, afastadas as particularidades e dogmatismos de crença e doutrina, dos pensamentos dogmáticos, no lugar do Deus ou Dogma de cada um dominará agora um Deus único, o homem - igual, virtuosos, universal e livre (UP 191, r158) como ninguém, mais do que foram capazes de conceber os iluministas clássicos no século XVIII. De fato, se os homens estão procurando uma comunidade ou laço, dentro dos quais suas desigualdades não sejam mais essenciais, o serem todos "homens" é certamente o que pode haver de mais comum entre eles (184, r151-52). Enquanto for assim, no entanto, conclui Stirner, não haverá lugar para o indivíduo real de carne e osso, singular, particular, como tal, mas apenas para ideais, novos senhores e novas hierarquias - alienantes e opressivos.

Essa é a posição de Stirner sobre as grandes ideologias do seu tempo, expostas em sua terminologia peculiar e em sua retórica ironista. Para ele, o "liberalismo político" (que frequentemente no texto do Único evoca mais Rousseau do que Locke) representaria ainda um grau menor de despossuimento do indivíduo. E o comunismo, o passo posterior, final, representaria seu grau mais completo. ${ }^{3}$ É que o primeiro, aceitando os homens ainda como proprietários, deixaria à concorrência o estabelecimento da quota de propriedade de cada um, e aí o "egoísmo" ainda conservaria algum espaço (UP 330, r292). Já o comunismo, que representaria a crítica imediata do primeiro e, para Stirner, seu

3 Marx, o mais ferrenho crítico de Stirner, entende que, no Único, o "liberalismo social" corresponde - para Stirner - à última etapa da alienação cristã-moderna, em prejuízo do indivíduo, do homem comum, real (IA 413). Na verdade, depois (pelo menos em termos lógico-dialéticos) do "liberalismo social", para o autor do Único, ainda haveria por desmistificar e descartar o "liberalismo especulativo e humano", de Bruno Bauer, que iria ainda mais longe do que o simples comunismo. No entanto, o ponto de vista social de Marx, como o comunismo alemão de um modo geral, trata de absorver como suas todas as reivindicações da especulação baueriana. E o próprio Stirner, que muitas vezes distingue esses dois momentos finais da progressão expropriadora dos indivíduos, acaba por autorizar, como veremos, a discussão do comunismo como alegada libertação final e completa - do "homem".

\begin{tabular}{|c|c|c|c|c|}
\hline Qevista Dialectus & Ano 5 & n. 12 & Janeiro - Julho 2018 & p. $163-208$ \\
\hline
\end{tabular}




\section{O ANTIPLATONISMO PRÁTICO DE MAX STIRNER...}

José Crisóstomo de Souza

desenvolvimento lógico, não deixaria absolutamente nada ao indivíduo. Se somos supostamente livres e, entretanto, vivemos sob a opressão dos egoístas proprietários, por acaso devemos nos tornar também egoístas? "Deus nos livre! Preferimos tornar impossível todo egoísmo". Tal seria, segundo Stirner, o lema dos comunistas: "Ninguém terá nada, para que 'todos' tenham” (158, r127). E quem é essa pessoa proprietária aqui chamada de "todos" e até dotada de um corpo (o corpo social)? A sociedade, ora bolas, "nós somos seu corpo", damos-lhe corpo e realidade, entenderiam os "liberais sociais". Não é nada disso, porém, Stirner replica: Vocês juntos, associados, não constituem um corpo, cada um de vocês tem um corpo. A sociedade pode servir-se dos corpos dos indivíduos, mas não tem um corpo seu, uma existência por si. “Tal como a nação dos políticos, ela não sria mais do que um espírito, um fantasma, e seu corpo apenas um espectro."

$\mathrm{Na}$ corporificação da sociedade, entenda-se, Stirner aponta na verdade sua hipostasiação como Substância real e Sujeito verdadeiro, e chama a atenção sobre como tal transformação procederia em última análise contra a corporeidade singular do indivíduo, base de sua individualidade e de toda subjetividade autêntica. A sociedade não poderia ser senhor nem proprietário, que distribua judiciosamente seus bens entre os indivíduos. Por aí, a sociedade dos socialistas e comunistas, da qual se receberia tudo, não passaria de um novo e todo poderoso Ser Supremo que, como tal, impõe sobretudo "serviços" e "deveres" (UP 167, r135). Para Stirner, ao contrário de Hegel ou Marx, a sociedade é apenas um instrumento ou meio, do qual devemos nos servir, sem que estejam envolvidos nisso quaisquer deveres sociais, mas unicamente interesse e negociação. Os "liberais sociais" não podem, entretanto, pensar desse modo porque estão ainda imbuídos de um "princípio religioso". Contra o indivíduo real, egoísta, querem a "Sociedade justa", como outros antes quiseram o Estado divino ou sagrado (166-67, r135).

Para os liberais sociais de Stirner, os liberais políticos fariam o trabalho igualitarista apenas pela metade, deixando por isso subsistir a desigualdade decorrente do "ter" dos indivíduos. Além disso, pelo fato de os segundos protegerem contra uns a propriedade de outros, seu Estado e seu direito separam os indivíduos, fazendo da fraternidade uma palavra oca, e da liberdade apenas uma indiferença recíproca (como entende Marx na "Questão judaica”). Os liberais sociais constatariam que "o ter faz o homem”, e que, no entanto, “pelo seu ter, as pessoas são mantidas [no liberalismo político]

\begin{tabular}{|l|l|l|l|l|}
\hline Q Povista Dialectus & Ano 5 & n. 12 & Janeiro - Julho 2018 & p. 163-208 \\
\hline
\end{tabular}




\section{O ANTIPLATONISMO PRÁTICO DE MAX STIRNER... José Crisóstomo de Souza}

ainda inteiramente desiguais". Concluem então que ninguém deve ter, tal como os liberais políticos concluíram "que ninguém deve comandar”. Ora, dirá Stirner, diante do grande soberano que é o Estado ficamos tornados iguais como zeros, e agora, diante do supremo proprietário que é a Sociedade, não passamos todos de "miseráveis". O liberalismo social representaria assim o mais completo roubo já perpetrado contra a personalidade (ou pessoalidade), em benefício da humanidade! (UP 158-60, r128-29).

O comunismo entenderia que a dignidade do indivíduo não está na igualdade diante do Estado e da lei, mas no fato de que "existimos uns para e pelos outros". Você cuida de meus interesses, eu dos seus, você trabalha para me vestir, eu para lhe instruir, e assim por diante. É pelo trabalho que somos "um-para-o-outro", e é ele que faz nossa igualdade e nossa dignidade (UP 161, r130). ${ }^{4}$ Nele estaria o ser social e verdadeiramente público do homem. Agora é o trabalho que dá direito ao prazer e à propriedade, como antes era a virtude que merecia a felicidade (UP 244, r209). ${ }^{5}$ Os comunistas tomariam como ponto de partida o fato, próprio do regime burguês, de que é o trabalho que faz valer o trabalhador, formulando então a exigência de que tal trabalho seja valorizado como o essencial (161-62, r130-31). Para Stirner, porém, não é pelo trabalho que se tem direito ao usufruto do que quer que seja: quem usufrui tem o direito de usufruir, e as coisas pertencem a quem for capaz de se apossar delas e de não deixar que elas lhe sejam tomadas (244, r209). Pensando assim, para ele, os próprios trabalhadores se dariam bem melhor.

De acordo com o socialismo, todos deverão ser produtores, e a sociedade dará a cada um segundo seu trabalho. Stirner não diz expressamente, mas podemos supor que, mesmo quando o desenvolvimento da produção permitir a abolição dessa medida e a cada um for dado segundo as suas necessidades, para ele estas não deverão ser menos necessidades "humanas", para serem legítimas e consideradas De qualquer modo, em sendo o trabalho o princípio do comunismo, seus motivos não seriam somente os que vimos até aqui. Sob o cristianismo tradicional, bastava aos homens serem bons cristãos para realizarem sua vocação e adquirirem a dignidade de filhos de Deus. E as classes oprimidas

4 O "liberal social” Moses Hess, aliado de Marx, não regateará em proclamar: "Queremos o ser-um-para-ooutro", enquanto "os filósofos" - representados para Hess, principalmente, por Bruno Bauer e Max Stirner - "mover-se-iam no interior da categoria do "em-e-para-si-mesmo" (UF, 370-71, c57-8).

5 O que vem em continuação da tese do "liberal político" John Locke, para quem, se Deus deu o mundo aos homens para usufruírem dele, é pelo trabalho que o indivíduo se apropria legitimamente de uma parte do mesmo, e é o trabalho que dá a medida do que lhe cabe com propriedade (Locke, Segundo Tratado, V).

\begin{tabular}{|l|l|l|l|l|}
\hline Revista Oialectus & Ano 5 & n. 12 & Janeiro - Julho 2018 & p. 163-208 \\
\hline
\end{tabular}




\section{O ANTIPLATONISMO PRÁTICO DE MAX STIRNER... José Crisóstomo de Souza}

podiam suportar qualquer coisa enquanto o cristianismo sufocava suas queixas e revoltas. O humanismo, no entanto, passou a ensinar que cada um tem uma humanidade a cultivar, e que, nesse caso, não é indiferente o trabalho que se fez e as condições em que é feito. De modo algum, por exemplo, cabe agora trabalhar como uma máquina, e numa atividade em que não se encontre satisfação e crescimento humanos. A própria burguesia proclamou o evangelho da "felicidade terrena" e mostrou que ela supõe cultura e riqueza.

O liberalismo político declarou guerra ao arbítrio de uns indivíduos sobre outros, mas deixou subsistir o das circunstâncias, que, por exemplo, arruína um ramo da indústria e desemprega milhares de trabalhadores. Diante disso, diriam os liberais sociais, é preciso mudar as circunstâncias e criar uma nova ordem que ponha fim a tais eventualidades. A concorrência revelou-se um jogo de azar, das especulações da bolsa à busca de emprego; uma situação que ofenderia toda decência e revoltaria os que vítima. É a isso que os liberais sociais quereriam pôr fim, construindo uma sociedade em que os homens não dependam da sorte, mas sejam verdadeiramente livres de toda imposição exterior. O "princípio do trabalho", diz Stirner, supera o da concorrência capitalista. Em contrapartida, no entanto, tal princípio quer fazer do indivíduo essencialmente um trabalhador, e entregá-lo à soberania da Sociedade - da qual ele receberá aquilo de que precisa para ser "homem" e à qual deverá reverência e obrigação (UP 162-67, r131-35). Diante da Sociedade, enquanto indivíduo egoísta, com necessidades e desejos pessoais e contingentes, ele não merecerá absolutamente nada.

Os liberais políticos de Stirner - os expoentes da filosofia política moderna (especialmente Rousseau) - empenharam-se em anular todo capricho ou vontade particular, para instaurar o império da vontade geral que é a lei. Teriam deixado de compreender, contudo, que a propriedade garante ainda ao "próprio" um espaço demasiado amplo. Os liberais sociais tratam de suprimi-la, deixando de ver, porém, que ela ainda se perpetua na individualidade peculiar de cada um. Pois não só o dinheiro e os bens materiais seriam propriedade, minha opinião seria igualmente algo meu e próprio, onde o egoísmo pode se abrigar. Por isso, em última análise, é necessário que também toda opinião seja abolida ou tornada impessoal: "Da mesma maneira que a vontade foi conferida ao Estado e a propriedade à Sociedade”, diz Stirner, “a opinião também deve remeter a algo de universal,

\begin{tabular}{|l|l|l|l|l|}
\hline Q Povista Dialectus & Ano 5 & n. 12 & Janeiro - Julho 2018 & p. 163-208 \\
\hline
\end{tabular}




\section{O ANTIPLATONISMO PRÁTICO DE MAX STIRNER... José Crisóstomo de Souza}

o 'Homem', e fazer-se uma opinião humana universal". ${ }^{6}$ Em lugar de minha fé ou meu ideal, que prevaleça agora um credo humano universal, o da liberdade pura, uma crença racional e conforme à essência do homem (UP 172-73, r141). É disso que vai se encarregar especificamente o "liberalismo humano" ou "crítica humana livre", de Bruno Bauer, no prolongamento do liberalismo social.

Assim se completaria o ciclo do "liberalismo" moderno para Stirner, cujo "bom princípio" é o homem, e cujo mau são o egoísmo e o privado (UP 172-73, r140-1). O cristianismo teria sido desde o início incapaz de apreciar o indivíduo singular, no qual só viu dependência e limitação; o cristianismo teria sido sempre uma "doutrina da vida comum", do homem com Deus e com o outro. Sua relação com o que é "próprio" (em alemão, Eigen) pode ser vista na rejeição ao que expressam palavras alemãs como Eigennutz (interesse egoísta), Eigensinn e Eigenwille (teimosia, capricho), Eigenliebe (egotismo) etc. (219, r186), pois o cristianismo nos marcou na própria linguagem. Do mesmo modo, o liberalismo humano, ou crítica humana, não passaria da mais acabada “doutrina social”. Pois só o homem pleno que ela almeja poderá viver perfeitamente bem numa sociedade "humana". O liberalismo humano trata de eliminar "tudo o que separa o homem do homem", atingindo o ápice do verdadeiro princípio social, "o princípio cristão do amor" - conclui Stirner provocativamente. O liberalismo humano ou crítica humana seria a tentativa mais avançada e radical de despojar o homem de toda particularidade e egoísmo, combatendo de frente sua individualidade própria e sua unicidade (179-80, r14748).

O liberal humano prometeria uma verdadeira sociedade, onde não haverá lugar para o que cada indivíduo tem de particular (UP 171-72, r140). Depois do Estado sem privilégios, e da Sociedade sem propriedade privada, a Sociedade propriamente humana representaria o Estado e a Sociedade mais universais, onde todos se ocupariam só e espontaneamente do interesse humano (UP 172, r140-41). O liberalismo humano deseja que os indivíduos se libertem de toda limitação, para serem apenas "homens" - em vez de judeus, cristãos, trabalhadores, patrões, alemães ou o que quer que seja (189, r156). Nem limitados cidadãos, nem fixados trabalhadores, mas agora homens sem limites. Frente ao

6 Um "liberal político" rigoroso como Hobbes já percebera que o "julgamento privado do bom e do mal”, ao lado da "atribuição absoluta de propriedade aos súditos", pode levar ao enfraquecimento e à dissolução do Estado ou corpo político. Hobbes, Leviathan, I, XXVIII.

\begin{tabular}{|l|l|l|l|l|}
\hline Qevista Dialectus & Ano 5 & n. 12 & Janeiro - Julho 2018 & p. 163-208 \\
\hline
\end{tabular}




\section{O ANTIPLATONISMO PRÁTICO DE MAX STIRNER... José Crisóstomo de Souza}

liberal social, o liberal humano faz a crítica do trabalho, enquanto esse está submetido, mesmo na sociedade dos trabalhadores, à necessidade e à sociedade. $\mathrm{O}$ trabalho seria ainda uma atividade "sem espírito", que precisa ser recompensada pelo lazer (174-79). Essas aliás, como sabemos, são reivindicações que se encontram absorvidas no programa do "liberalismo social' (o comunismo) de Marx, que critica o "comunismo grosseiro" por negar a vida espiritual e instaurar o trabalho ainda como uma imposição (v.g. MEF 85-7). ${ }^{7}$

No Único e Sua Propriedade, Stirner acrescenta uma observação ${ }^{8}$ sobre a inflexão que a Crítica humana, de Bruno Bauer, teria sofrido quando a elaboração do livro já estava adiantada. ${ }^{9}$ A crítica baueriana percebia agora que a "massa" (o povo, como de preferência diriam os "liberais") opõe-se ao "espírito" e à "teoria", e que os "interesses humanos" não se confundem com "interesses políticos". Mais do que antes, a nova Crítica pura, ou Crítica crítica, só vê por toda parte "o inumano" - sendo que o "humano", Stirner dirá, "está apenas em sua cabeça" (a de Bauer). A Crítica se volta agora contra tudo que lhe pareça ainda parcial, e que mantenha o indivíduo limitado e prisioneiro. Sua preocupação está em não ser mais, inadvertidamente, dogmática, e para isso chega às vezes a se afastar, não só de objetivos políticos restritos, mas também da própria noção de "homem" e de "humanidade", que agora the parecem podem ser dogmas fixados, substancializados. No entanto, acha Stirner, com isso a Crítica pura, ou Crítica crítica (vide a Sagrada Família, de Marx e Engels), permanece ainda no mesmo terreno - o do pensamento. Não se quer fixar em noção ou pensamento algum, e sobrepõe o pensar, livre, a qualquer pensamento particular. Com isso, porém, é o "livre pensar" que se torna o novo dogma, e é o mundo do pensamento puro que atinge sua perfeição.

Essa seria então, para Stirner, a política da igualdade essencial dos homens, de sua natureza, junto com isso, também essencialmente universal, comunitária, cooperativa,

7 O comunismo vulgar ou grosseiro não suprimiria a categoria de trabalhador, mas em vez disso a estenderia a todos os homens. Para Marx, que ainda na Ideologia alemã levanta o objetivo da "abolição do trabalho", tal comunismo está marcado pelo egoísmo da propriedade privada e por necessidades ainda não propriamente humanas (MEF 87).

8 Cf. UP 192-200, r167-69.

9 Stirner examina o ${ }^{\circ} 8$ da Allgemeine Literatururzeitung (do grupo de intelectuais liderados por Bauer), de julho de 1844, sobre o qual Marx também se deteve na Sagrada família. Na Ideologia alemã, Marx trata de desconhecer a crítica stirneriana a Bruno Bauer e de apresentar os dois como íntimos aliados. Os responsáveis pela edição francesa da Sagrada família (Éditions Sociales, 1972) chegam a declarar que as diferenças entre Stirner e Bauer giravam apenas em torno de "problemas pessoais mesquinhos" (SF 178n), o que é inteiramente falso.

\begin{tabular}{|c|c|c|c|c|}
\hline Qevista Dialectus & Ano 5 & n. 12 & Janeiro - Julho 2018 & p. $163-208$ \\
\hline
\end{tabular}




\section{O ANTIPLATONISMO PRÁTICO DE MAX STIRNER...}

José Crisóstomo de Souza

harmônica, com as decorrentes obrigações que dela emanam e autorizações que conferem aos que falarem em seu nome - a política dos intelectuais, ele diria Mas, a essa altura da Modernidade ocidental, depois dessa progressiva e finalmente total expropriação dos indivíduos reais, pelos liberalismos político, social e humano, mas em todo caso potencialmente exauridos o cristianismo e os credos que lhe substituíram, o indivíduo, desenvantado dessas coisas, não terá outra saída senão finalmente afirmar-se ele próprio radicalmente enquanto proprietário, pelo menos de si mesmo, e único, à sua maneira e possibilidade. Essa a virada dialética proposta pelo Único.

\section{A Relação de Livre Associação dos Indivíduos enquanto Únicos e Egoístas}

Para Stirner, enquanto Proudhon ${ }^{10}$, os comunistas e os humanos (ou humanistas mais completos) lutam todos contra o egoísmo, não passam de "homens religiosos" que servem humildemente a algo de universal, algo que eles não são. Suas respectivas concepções políticas e sociais representam apenas consequências do princípio cristão do amor a algo de geral, que não sou eu e que não é ninguém. Os comunistas estão convencidos de que a comunidade deve ser a proprietária, mas para Stirner, ao contrário, o proprietário não haverá de ser nem Deus, nem o homem, nem a sociedade, mas, em certo sentido e em certo terreno, apenas o indivíduo, o eu, eu (UP 315, r 277-78). "Só eu sou proprietário", e não são os outros que haverão de dizer o que me cabe. Sim, posso me entender com eles a respeito da minha propriedade, mas me insurgirei sempre que meu interesse for outro. De tal modo, acha Stirner, a propriedade jamais será, para mim, sagrada ou alienada. Enquanto o comunista se comportaria "como um mendigo", o egoísta responderia: "eu tomo o que preciso" (325, r287) - da maneira que eu puder.

As tentativas de submeter a propriedade a "leis "razoáveis estariam inspiradas no Amor, mas desembocam "num confuso mar de regulamentações." E, seja no projeto dos socialistas, que querem distribuir a propriedade, seja no dos comunistas, que desejam a propriedade comum, os indivíduos continuariam dependentes e submissos. Pois a Autoridade distribuidora é quem dirá o que me/lhes cabe, e sua "riqueza comum" representará para mim o mesmo impedimento que a particular. $\mathrm{Na}$ verdade, minha

10 Stirner frequentemente refere-se a Proudhon como representante do socialismo, e a Weitling e Hess como os expoentes do comunismo, sendo esses os dois grandes ramos do "liberalismo social".

\begin{tabular}{|l|l|l|l|l|}
\hline Revista Dialectus & Ano 5 & n. 12 & Janeiro - Julho 2018 & p. 163-208 \\
\hline
\end{tabular}




\section{O ANTIPLATONISMO PRÁTICO DE MAX STIRNER... José Crisóstomo de Souza}

dependência será ainda maior do que é hoje, e com relação a esse todo-poderoso Outro, que é a Coletividade por aqueles concebida. Embora esteja em luta com o Estado, Stirner alega, o comunismo quer de fato apenas "um novo Estado" (Status), mais estado ainda do que o atual, em que meu livre movimento estará bloqueado por um Poder imensamente superior. Os comunistas têm razão em se opor à opressão da propriedade burguesa, "mas o poder que entregam à Coletividade é ainda mais terrível” (UP 323-42, r285-86).

O caminho que o egoísmo stirneriano propõe para acabar com a miséria e o despossuimento é oposto ao do liberalismo social, seja na sua versão socialista ou comunista. "A questão da propriedade", frisa Stirner, "não é tão fácil de resolver como pensam os sociais." Em vez de suprimir a propriedade, é preciso tirá-la das mãos de “fantasmas" e declará-la "minha", pondo fim à ideia de que não estou autorizado a pegar o que puder e o que me interessa (UP 326, r287-88). Em vez de esperar que uma Autoridade "justa”, em nome da Coletividade, me premie por meus merecimentos (aos olhos dela), tratarei de tomar aquilo de que necessito. É verdade que os egoístas sempre agiram assim, mas agora isso não seria mais considerado com desprezo; o "tomar algo para si" seria antes reconhecido como o que cabe a todo egoísta "em acordo consigo mesmo" (324, r286). Francamente falando, ficaria assim abertamente declarada uma benvinda "guerra de todos contra todos".

Pois, no egoísmo, ninguém renunciaria a nada pelo Bem universal ou da maioria, se de algum modo também não lhe conviesse, e cada um trataria de assegurar o que é seu, associando-se a outros, mas apenas em seu próprio interesse (UP 388, r346). Se comisso os que nada têm perdido todo o respeito que os inibe, vão agora querer demais, ninguém terá por isso que lhes presentear com coisa alguma. Mas tampouco deverá chamar de "criminoso" a quem der as costas a esmolas e tratar de conseguir qualquer coisa por si mesmo. A que isso conduzirá, não se sabe, diz Stirner, o certo, porém, é que nenhuma tentativa baseada no "Amor" lhes reservou até agora melhor sorte. "Os pobres só se tornarão livres e proprietários quando se insurgirem ou levantarem" (325-27, r287-89). Tudo que o amor e os belos sentimentos produziram até hoje foi simplesmente miséria. A esperança estaria agora no tomar, na usurpação, não na abnegação. A salvação virá dos que tomarão, e não de espíritos misericordiosos e generosos $(389$, r346).

\begin{tabular}{|c|c|c|c|c|}
\hline Ronista Q Dialectus & Ano 5 & n. 12 & Janeiro - Julho 2018 & p. $163-208$ \\
\hline
\end{tabular}




\section{O ANTIPLATONISMO PRÁTICO DE MAX STIRNER... José Crisóstomo de Souza}

Mas como? Diferente do que pensariam os comunistas, minha riqueza não consiste apenas no meu trabalho, mas em tudo de que sou capaz: "Aquilo que podes, esta é a tua riqueza!" "11 (UP 332, r 294). O egoísta stirneriano não almejaria qualquer privilégio, nem quereria prejudicar ninguém, apenas não quer medir-se com uma medida alheia. Ele não pretende invocar o direito a seu favor, nem quer que haja qualquer direito; deseja apenas "ser tudo o que pode ser e ter tudo o que pode ter" (185). Na opinião do Único é aquele egoísmo que sai menos favorecido na concorrência que levanta a questão da repartição de bens e, apoiando-se no "princípio da humanidade", quer que cada homem tenha apenas "tanto quanto lhe for necessário". Mas "as necessidades do 'homem' não são uma medida aplicável às minhas" - na verdade "devo ter tanto quanto sou capaz de me apropriar" (330-31, r293).

Apesar disso, Stirner supreendentemente imagina que o comunismo pode ter algum uso no nível da "organização do trabalho"12 (UP 337, r298), que poderia abranger apenas as atividades que qualquer um pode fazer - o que se pode chamar de trabalhos humanos, em que a individualidade não entra em jogo. Haveria trabalhos que permanecem inapelavelmente egoístas, que ninguém pode fazer pelo outro - os trabalhos "de único". "Ninguém pode escrever tuas composições musicais, nem pintar teus quadros; como ninguém pode substituir as obras de Rafael." A sociedade não pode se ocupar de tais trabalhos, e sua intervenção nesse terreno pode ser até prejudicial. "O único saberá se destacar, graças à sua obra, da sociedade, mas a sociedade por si jamais produzirá um único". Para os trabalhos humanos, entretanto, Stirner admite, a união pode ser desejável, para que não dissipemos nossos esforços nos trabalhos corriqueiros, "como acontece agora sob o regime da concorrência" (336-37, r298).

Mesmo assim, acha, todo cuidado será pouco quando o indivíduo procurar contar com a sociedade para que esta o ajude a realizar seus objetivos. Porque ela logo tratará de lhe prescrever leis e de impor-se como Ser supremo e Supremo legislador. Não se pode esperar destruir completamente a "religião" - agora em suas versões modernas - sem

11 Stirner joga com os significados da palavra alemã Vermoegen: poder (verbo), mas também riqueza, patrimônio.

12 Marx trata de eliminar essa afirmação, numa das citações do Único que faz na Ideologia alemã (IA 430). Ele não gostaria de embaralhar os campos, e tampouco deve lhe agradar essa consideração inteiramente instrumental do comunismo.

\begin{tabular}{|c|c|c|c|c|}
\hline Qevista Dialectus & Ano 5 & n. 12 & Janeiro - Julho 2018 & p. $163-208$ \\
\hline
\end{tabular}




\section{O ANTIPLATONISMO PRÁTICO DE MAX STIRNER... José Crisóstomo de Souza}

antes subverter a sociedade e tudo o que ela implica como princípio. E isso o comunismo não fará, pois nele apenas atingiríamos a apoteose do "estado do amor", onde tudo deve ser comum, para que reine finalmente a igualdade, junto com a qual virá finalmente a verdadeira liberdade. Mas liberdade de quem, pergunta Stirner, senão da Sociedade? (UP $389-90$, r347-48)

Em vez de fundarem suas sociedades sobre si mesmos, buscando seu próprio desenvolvimento e se fazendo valer, os homens têm até aqui fundado sociedades que a eles se impõem como poderosas Pessoas Morais, capazes de lhes inspirarem receio e reverência (UP 267-68, r231-32). A palavra alemã Gesellschaft (sociedade), que teria como raiz Saal (sala), por si só já sugere que viver em sociedade é como estar encerrado por paredes, e não associado através de relações livremente estabelecidas. As relações autênticas seriam na verdade independentes da sociedade, e implicariam numa fundamental reciprocidade (267, r239). As atuais Sociedades e Estados, Stirner prossegue, têm ainda uma existência autônoma, independente de nós, constituindo-se num estado de coisas que não pode ser por nós “dissolvido" (282-83, r245-46). Em oposição a isso, o "egoísta" trata de "utilizar-se" da sociedade como sua propriedade e criatura. Ele a "aniquila" para instaurar em seu lugar a união sempre fluida que é a "associação dos egoístas" (231, 282-83, r190, 245-46). E isso significa refazer as relações sociais como relações entre indivíduos, entre eus, relações minhas. As lutas atuais contra o status quo são entendidas erroneamente, Stirner acredita, como devendo conduzir a um "estado de coisas" melhor. Na verdade, dirigem-se finalmente contra todo estado ou status! (282-83, r245-46).

Diante disso, é fácil imaginar que Stirner é o campeão do que Marx chamaria depois de "robinsonada": conceber um indivíduo isolado original (como um Robinson Crusoé), que precederia historicamente a sociedade ou poderia existir fora dela. Ao contrário disso, no entanto, Stirner entende que mesmo o "isolamento" e a "separação" que a concorrência cria supõem "um laço comum" ou "social" - isso ele sabe. Ele diz expressamente (como se respondesse por antecipação ao Marx da "Introdução de 1857") que os caçadores e pescadores dispersos e isolados estão também em sociedade (AC 12829). Não só sabe muito bem que os homens precisam do trabalho uns dos outros para viver, como defende que "o estado original do homem não é o isolamento ou a solidão, mas justamente a sociedade" (UP 384, r342). A sociedade é o nosso Estado de Natureza. Só que

\begin{tabular}{|l|l|l|l|l|}
\hline Qovista Dialectus & Ano 5 & n. 12 & Janeiro - Julho 2018 & p. 163-208 \\
\hline
\end{tabular}




\section{O ANTIPLATONISMO PRÁTICO DE MAX STIRNER... José Crisóstomo de Souza}

essa união social originária iria sendo pouco aos poucos relaxada, "à medida que aprendemos a nos conhecer", até atingir sua completa dissolução.

Estamos aqui de novo em plena "biografia" e "filosofia da história" de Stirner: ${ }^{13}$ a criança logo preferirá "as relações que desenvolve com seus semelhantes, à sociedade na qual não entrou, mas apenas nasceu”. O intercâmbio e a associação que assim se constituem representam a própria dissolução da sociedade, embora possam "degenerar" e "cristalizar-se" novamente em sociedade - "como um pensamento pode-se cristalizar em ideia fixa" (UP 384, r342). Pois, tal como o pensar dotado de "energia pensante" é uma perpétua "negação" de todos os pensamentos, a "associação" (que é como Stirner denomina a interação social que propõe ou constada como tendência) só pode ser "um permanente associar-se" (385, r342).

Rousseau, no Contrato Social, chama seu pacto de "ato de associação", e a questão que se propõe é constituir uma sociedade em que cada um seja "tão livre quanto antes" - mesmo que às custas de sua "alienação total à comunidade toda" ${ }^{13}$ Stirner não quer tanto, não imagina um "antes" inteiramente livre, e certamente desconfiaria do resultado do negócio proposto. Embora conhecido como anarquista, não lhe preocupa que, como o Estado, a sociedade também represente uma certa restrição à liberdade: "Devo admitir que minha liberdade seja limitada por tudo que é mais forte do que eu, inclusive pelos outros homens." Pois o problema não está em que a sociedade me tire algumas liberdades, já que me oferece outras. A associação que ele pretende poderá até oferecer uma liberdade maior, mas não é aí que se encontra a diferença essencial entre o Estado e a associação. A questão está, isto sim, na minha individualidade, que o Estado e a Sociedade procuram subtrair (UP 385-87, r343-44).

O problema está, então, em que toda sociedade ou comunidade acaba por se tornar uma Autoridade que exige de você sujeição - objetiva e subjetiva. Ela poderá até ser tolerante com relação a críticas que considerar "bem-intencionadas", mas não admitirá que seus membros se ponham acima dela. "É preciso deixar intacta e respeitar como sagrada a substância da sociedade”. Qual a diferença entre ter limitada apenas a liberdade e ter restringida a individualidade? No primeiro caso, diz Stirner, a sociedade será tão-somente

13 Sobre tal "biografia" e sobre a "filosofia da história" de Stirner, ver nosso A Questão da Individualidade, p.13-43.

1 Cf. Jean-Jacques Rousseau, Du Contrat social, I, p.4.

\begin{tabular}{|l|l|l|l|l|}
\hline Revista Oialectus & Ano 5 & n. 12 & Janeiro - Julho 2018 & p. 163-208 \\
\hline
\end{tabular}




\section{O ANTIPLATONISMO PRÁTICO DE MAX STIRNER...}

José Crisóstomo de Souza

uma união; no segundo, trata-se de um poder "por si", que devo "respeitar", e não simplesmente "consumir". No caso do Estado, ele é o próprio inimigo da individualidade, quando trata de exercer sobre mim uma "influência moral": "Ele suprime o meu eu, para se pôr em seu lugar como "meu eu verdadeiro"”. Já a associação é apenas "minha colaboradora", e não "uma potência espiritual acima do meu espírito". Em resumo, o Estado e a Sociedade, em linguagem stirneriana, representariam algo de "sagrado", mas a “associação" não, ela seria simplesmente "minha” (UP 385-87; 393, r343-45, 351).

Stirner admite que de certo modo - mas só aparentemente - a sociedade dos comunistas se aproxima da sua associação (UP 387, r345). Com efeito, Marx mesmo insiste na superação da autonomização da sociedade com relação aos indivíduos. E reconhece que esta não tem sido de modo algum uma união voluntária, como pretendia o contrato social de Rousseau, mas uma vinculação "necessária" - definida impositivamente pela divisão do trabalho (IA 94-7 passim). ${ }^{2}$ Entretanto, de acordo com Marx, os indivíduos só poderão submeter tal Potência e "entrar em relação uns com os outros enquanto indivíduos" (102) pela instauração da comunidade universal $(94,97)$. Seu desenvolvimento e sua afirmação (sic) efetivamente pessoais - e omnilaterais - supõem a superação de sua "dispersão" e “independência" recíprocas (102), e a instauração da "comunidade de proletários revolucionários" (96).

Para Stirner, ao contrário, a comunidade é impossível e a igualdade uma ilusão: “somos iguais apenas enquanto pensados, e não como somos em carne e osso." Por isto, em vez de aspirar à Comunidade humana, é melhor ter em vista a particularidade, e "procurar nos outros apenas meios" para nosso uso (UP 390-91, r348-49). Eu me entenderei com quem eu puder utilizar, e me unirei a quem puder aumentar minha potência - assim seria a associação stirneriana (391, r349). Ela não se constituiria nem por laços naturais, como a família, a nação ou a humanidade (onde os indivíduos seriam apenas "exemplares do mesmo gênero humano"), nem por um laço espiritual, como no caso de um partido ou uma igreja (onde eles seriam apenas "membros" ou "elos" do Espírito, de um mesmo Corpo Místico) (392, r349).

2 Quando Marx fala da sociedade comunista como de uma "união" de indivíduos "livremente associados", "que dela participam enquanto indivíduos" (IA 96,98), ele parece estar prestando tributo a Stirner.

\begin{tabular}{|c|c|c|c|c|}
\hline Ronista Dialectus & Ano 5 & n. 12 & Janeiro - Julho 2018 & p. $163-208$ \\
\hline
\end{tabular}




\section{O ANTIPLATONISMO PRÁTICO DE MAX STIRNER... \\ José Crisóstomo de Souza}

Como ficaria então a propriedade em sentido usual, na associação stirneriana? Embora Stirner não se caracterize como um propositor de sistemas sociais, alguma coisa deve ser mencionada a esse respeito, principalmente porque é um ponto sobre o qual Marx, na Ideologia Alemã, vai concentrar suas críticas. Para Stirner, só na associação a propriedade é verdadeiramente reconhecida, "porque aí ninguém recebe seus bens como uma concessão de quem quer que seja". O comunismo, ao contrário, simplesmente levaria mais longe um "regime feudal", a "ausência de propriedade", as quais ainda caracterizam a evolução "religiosa" moderna. O Estado até aqui tem sido concebido em última análise como o Senhor que zelosamente concede seus bens segundo seu interesse - para domesticar o egoísta, para "dirigir seus desejos para si”, para convertê-lo em "cidadão" (UP 392-93, r349-50). ${ }^{3}$

Stirner está aqui se digladiando com boa parte da teoria política moderna coisa que Marx, que prefere apontar tal Estado proprietário como absolutamente imaginário, trata de ignorar. ${ }^{4}$ Rousseau, em particular, deixa claro que o Estado deve ser "o senhor de todos os bens", os chamados "proprietários" ficando apenas como "depositários do bem público." ${ }^{5}$ No caso de sua proposta de Constituição para a Córsega, por exemplo, Rousseau não esconde que "gostaria que o Estado tivesse tudo, e que cada um tivesse participação nos bens comuns apenas na proporção de seus serviços." Para Stirner, a associação seria o contrário de tudo isso, enquanto no comunismo a tendência rousseauísta seria levada a seu termo (UP 393-94, r350-52).

Para a tristeza de seus críticos, e também de alguns pretensos seguidores, $O$ Único e sua propriedade não inclui nada parecido com uma verdadeira descrição da associação como forma ou modelo de organização social. Moses Hess, crítico humanista e comunista de Stirner, que gostaria de vê-la "ao menos no papel”, na falta disso a entende

3 Diante disso, como pôde Auguste Cornu entender (cf. Cornu, Marx e Engels, IV) que Stirner quer que o Estado garanta o acesso de todos os indivíduos à propriedade privada (p.352), ou pelo menos os meios para adquirir bens (p.356)?

4 Para Hobbes, por exemplo, é o soberano quem pode "prescrever as regras através das quais todo homem pode saber quais os bens de que pode gozar" (cf. Hobbes, Leviathan, II, cap.28), enquanto Espinosa advoga que cada cidadão só possuirá "o que puder reivindicar em virtude de um decreto da cidade" (cf. Espinosa, Tratado político, III, § 2).

5 Cf. Jean-Jacques Rousseau, Du contrat social, I, 9.

6 Rousseau, que acha impossível "destruir inteiramente a propriedade particular", pretende então "encerrála dentro dos limites mais estreitos possíveis", "dar-lhe uma regra" e "um freio", que a "dirija" e "subjugue": "Quero que a propriedade do Estado seja tão grande e tão forte e a dos cidadãos tão pequena e tão fraca quanto possível" (cf. Rousseau, Projeto de constituição para a Córsega, p.216).

\begin{tabular}{|c|c|c|c|c|}
\hline Qevista Dialectus & Ano 5 & n. 12 & Janeiro - Julho 2018 & p. $163-208$ \\
\hline
\end{tabular}




\section{O ANTIPLATONISMO PRÁTICO DE MAX STIRNER...}

José Crisóstomo de Souza

como uma réplica da sociedade conhecida, do seu próprio tempo europeu. Para ele, ao contrário, História até aqui só se conheceu associações egoístas, como a resultante servidão antiga e medieval e a "moderna servidão universal" (UF 60, c373-74). A concepção stirneriana simplesmente sancionaria a "forma perfeita do latrocínio" que é a concorrência burguesa. Em sua "tréplica" (sua resposta aos críticos de O Único e sua Propriedade), Stirner argumenta que sua associação, à qual volta e meia se refere no plural, pode não ser nada de tão misterioso ou monstruoso. Seus exemplos de "alegres associações egoístas", extraídas do cotidiano, são realmente desconcertantes: "crianças que se juntam para uma brincadeira", "conhecidos que se encontram na rua e se reúnem num bar", relações "com um amigo" ou "uma amante" etc. (AC 167-69). Quanto a sociedades em que a maioria se deixa lograr em suas "necessidades e interesses mais naturais", onde uns "se matam de trabalhar" para outros, elas paa ele nada teriam nem de associações nem de egoístas (UP 167). A esse respeito, Marx dirá que a ideia de uma associação "fundada sobre a exploração recíproca", onde ninguém seja privado do "necessário", é apenas um sonho de Stirner. Que, além do mais, inadvertidamente reconheceria "a existência de 'interesses naturais' e 'necessidades' comuns”, ou seja, “interesses e necessidades iguais” (IA 458).

\section{Apropriação e Fruição. A Emancipação dos Indivíduos: Rebeldia Pessoal ou Revolução Social?}

O que deveria então acabar definitivamente com a "nova feudalidade" que caracterizaria os tempos modernos de Stirner, e não deixaria espaço à individualidade? Para ele, não há de ser a Revolução, mas um ato pessoal de insurgir-se: a revolta. ${ }^{18}$ Conceber que ele - como Marx nos induz a acreditar - quer fazer assim papel de revolucionário em sentido clássico, que pretende mudar a sociedade através da crítica da religião e dos idealismos modernos, sabemos que é uma distorção desencaminhadora. ${ }^{19}$ Para Stirner, sua

18 Stirner usa nesse caso a palavra Empoerung, cuja tradução como "insurreição" ou "sublevação" facilitaria acompanhar as associações etimológicas que ele fará também nesse caso. Mas "revolta" ou, até melhor, "rebeldia" têm provavelmente uma conotação mais próxima do gesto - pessoal - que ele propõe.

19

Sobre isso, ver nosso A Questão da Individualidade. Através de Marx, vários autores incorrem nesse equívoco. Paul Thomas passa adiante a ideia de que, para os jovens hegelianos em geral, "tudo o que temos de fazer para mudar a realidade é ter o domínio de nossos pensamentos" (cf. Paul Thomas, 1975, p. 163). E Mario Rossi refere-se à "teoria revolucionária de Stirner", certamente inconsequente, como se se tratasse de um concorrente comparável à de Karl Marx (cf. Rossi, 1975, p.156).

\begin{tabular}{|c|c|c|c|c|}
\hline Qevista Dialectus & Ano 5 & n. 12 & Janeiro - Julho 2018 & p. $163-208$ \\
\hline
\end{tabular}




\section{O ANTIPLATONISMO PRÁTICO DE MAX STIRNER...}

José Crisóstomo de Souza

revolta é coisa bem diferente de uma revolução, que normalmente tem um alcance eminentemente político e social e visa um novo regime, uma nova ordem ou estado.

A revolta stirneriana poderia acarretar uma derrubada da ordem estabelecida, mas sem ter isso em vista. Pois não consiste em levantar bandeiras e programa, mas no levantar-se dos próprios indivíduos “sem preocupação pelas instituições que daí decorram”. Os revolucionários políticos preocupam-se com "questões constitucionais", da mesma maneira que os "sociais" tratam de conceber formas de uma organização futura. A revolta stirneriana não nos quer conduzir a um novo regime, mas a não nos deixarmos mais reger por quem ou o que quer que seja. E, prossegue o Único, como meu objetivo não é a derrubada de uma ordem ou estabelecimento de outra, minha "intenção" e "ação" não são políticas ou sociais, mas simplesmente “egoístas” (UP 397-98, r354-55) ${ }^{20}$.

Curiosamente, para dar a compreender melhor o que é sua revolta ou rebeldia, algo como uma nova autonomia ou independência, Stirner retorna aos começos do Cristianismo. Os "liberais" (seus modernos mais recentes, ideológicos), condenam os primeiros cristãos por haverem pregado obediência à ordem dominante (o dar a César o que é de César), deixando de responder à grande insatisfação política da época. Cristo, entretanto, acha Stirner, não quis ser um revolucionário ou liberal (em sentido stirneriano), pois não travou um combate político contra as autoridades, nem perseguiu como saída uma mudança geral das condições objetivas existentes. Em vez disso, apenas seguiu "seu próprio caminho" indiferente tanto ao Estado quanto a seus inimigos. Foi justamente um "rebelde, que se elevou" (emporhob) acima de tudo aquilo que o governo e seus opositores consideravam elevado, "e se desapegou de tudo a que eles permaneciam presos". Desse modo, Cristo teria abolido as bases mesmas do mundo pagão, e o Estado existente teve ao longo de certo tempo de perecer. "Precisamente porque não se ocupou da derrubada da ordem estabelecida, ele foi seu inimigo mais mortal e seu verdadeiro aniquilador" (UP 39899, r355-56). Stirner espera que aconteça agora, nos seus novos tempos, com relação ao

${ }^{20}$ O que faz com que Mario Rossi conclua que, se a revolta stirneriana não é nem política nem social, ela é então "religiosa" (Rossi, 1975, pp. 152-53). É interessante registar, entretanto, que o pensamento de Marx dá tanta importância a ordenamentos institucionais quanto Stirner, ou seja, nenhuma.

\begin{tabular}{|l|l|l|l|l|}
\hline Gevista Qialectus & Ano 5 & n. 12 & Janeiro - Julho 2018 & p. 163-208 \\
\hline
\end{tabular}




\section{O ANTIPLATONISMO PRÁTICO DE MAX STIRNER... José Crisóstomo de Souza}

mundo cristão, o mesmo que aconteceu com o "mundo pagão". E, para ele, "uma revolução só trará esse fim se uma revolta se realizar primeiro" (399-400, r356-57). ${ }^{21}$

Marx, que aparentemente não conheceu Nietzsche, entende que Max Stirner é o exemplo máximo da "fanfarronice" e a isso se reduziria a revolta stirneriana: uma síntese de fanfarronice e sentimentalidade (IA 330, d281) - esta última aparentemente incluída para devolver a acusação de "amorosos" feita aos comunistas. Sua revolta seria apenas uma "blasfêmia" - um "pecado" contra o "sagrado", um “desrespeito" que, Marx alega, não precisaria sequer manifestar-se exteriormente por algum gesto. A diferença entre a verdadeira revolução e a revolta "ideológica" de Stirner, acha nosso comunista, não está em que a primeira é uma ação política ou social enquanto a segunda é uma ação egoísta ou pessoal, mas tão-somente em que "uma é uma ação e a outra não é” (415, r361). Quanto ao "descontentamento consigo mesmo", com sua condição, que para Stirner é ponto de partida da autêntica revolta, não passaria de uma disposição de espírito característica de indivíduos abstratos de um meio pequeno-burguês. Stirner não concebe os indivíduos reais e suas relações, ${ }^{22}$ mas o "eu" e a "substância" à qual se opõe. Por isso não compreenderia, além do mais, que a revolução e os resultados a que chega estão determinados por certas condições. Mesmo quando a revolta recomenda que nos rejamos a nós mesmos, isso implicaria necessariamente, para Marx, que o indivíduo está obrigado a “deixar-se reger” pelo "Nós”, ainda que não esteja consciente disso (415-16, d362-63). Mas, Marx admite, as revoluções até hoje conduziram a novas instituições somente porque ocorreram no quadro de divisão do trabalho. A revolução comunista, que abole tal divisão, conduzirá finalmente ao desaparecimento definitivo desse tipo de coisa (418, d364).

Segundo Marx, Stirner suporia que os revolucionários sociais ou políticos estão vinculados entre si em primeiro lugar por um laço "ideológico" - um credo moderno em última análise dogmático, religioso." Suporia que eles abraçam a crença em um novo "espectro" ou "ideia fixa" (o homem, a igualdade, a humanidade) quando erguem bandeiras em vez de "erguerem-se" a si mesmos. Em contrapartida, para Marx, dando o troco, a

21 É interessante que o "ateu verdadeiro" Max Stirner leve tão a sério a figura de Cristo e mesmo encontre nele alguma afinidade com sua própria atitude rebelde. De qualquer modo, essa aproximação teria um alcance limitado, ao menos pelo fato de que as relações que o novo rebelde, stirneriano, entreterá com o mundo, as pessoas e os pensamentos, será de "fruição" de sua "propriedade" (UP 400, r357) - o que não seria o caso para Jesus Cristo.

22 Em alemão, a palavra Verhaeltnisse também pode ser traduzida como "condições".

\begin{tabular}{|l|l|l|l|l|}
\hline Revista Dialectus & Ano 5 & n. 12 & Janeiro - Julho 2018 & p. 163-208 \\
\hline
\end{tabular}




\section{O ANTIPLATONISMO PRÁTICO DE MAX STIRNER... José Crisóstomo de Souza}

filosofia stirnerana da revolta seria, em última análise, apenas a defesa do procedimento do "arrivista" - de quem procura elevar-se acima de uma determinada situação sem se preocupar com ela. Tal figura procuraria "desprender-se" da ordem existente "só na medida em que essa constitui um entrave para ele" (IA 419-20, d366). Num trecho riscado do manuscrito da Ideologia alemã, Marx completa: "É a velha moral do pequeno-burguês: tudo irá muito bem se cada um cuidar de se sair o melhor possível e não se preocupar com a maneira como vai o mundo". Observe-se, porém, que aqui como em outros casos, depois de pretender mostrar, com alegações materialistas, que não existe qualquer destino independente para o indivíduo, Marx não deixa, ainda assim, de fazer uma censura aos que se ocupam egoistamente apenas daquele destino, da sua própria sorte - como na revolta stirneriana. De qualquer modo, o fato é que Stirner não quer ser o filósofo da libertação ou da liberdade, mas da "apropriação" e do "ser próprio" - do ser próprio e norma de si mesmo. E nele, a apropriação não se restringe ao nível político-econômico, não começa por ele mesmo, e não subsume nela, como no caso de Marx, todas as outras apropriações.

A essa altura, para entender melhor a esclarecedora pendência entre os dois, antes de nos dedicarmos diretamente ao exame e à discussão da individualidade própria ou ser próprio stirneriano (Eigenheit), podemos apreciar, numa visão panorâmica, o percurso geral de sua constituição. O Único e Sua Propriedade está dividido em duas grandes metades. Na primeira, intitulada "O Homem", Max Stirner des(cons)trói o gigantesco edifício humano-moderno que nos tem abrigado/oprimido nos últimos tempos (ou até os meados do século XIX, quando o livro foi escrito). Na segunda parte, intitulada "Eu", a individualidade única se constrói, através de sucessivas (re)apropriações, recuperando tudo o que fora antes atribuído, agora não mais a Deus, mas ao "homem" - concebido como essência e generalidade, como "Ser Supremo para o homem" (como para Marx e Feuerbach, ou Robespierre e Sant-Juste). ${ }^{1}$

Segundo Stirner, sucedendo aos tempos propriamente feudais, em que reinava Deus, agora o período liberal ou humano, na busca mesma da liberdade, tem apenas prolongado nossa dependência - agora com relação ao homem. Livres do arbítrio pessoal (do Antigo Regime, feudal-absolutista), o poder que agora recebemos do novo Senhor,

Marx jocosamente apelida a primeira parte do Único, sobre o homem, de Antigo Testamento, e a segunda, sobre o único, de Novo Testamento, a boa nova egoísta ou "nova sabedoria" (IA 272, 303, d222; 253).

\begin{tabular}{|l|l|l|l|l|}
\hline Q Rovista Dialectus & Ano 5 & n. 12 & Janeiro - Julho 2018 & p. 163-208 \\
\hline
\end{tabular}




\section{O ANTIPLATONISMO PRÁTICO DE MAX STIRNER... José Crisóstomo de Souza}

como concessão, seria o direito. Livres (como projetado no socialismo e no comunismo) das vicissitudes das circunstâncias e da propriedade, também recebemos dele, Senhor, como grande "Mediador" transcendente que ordena nossas relações, nossa própria posição no mundo. Por último, livres de toda particularidade, nosso próprio - novo - eu nos é dado como concessão, já que nessas circunstâncias só será legítimo nosso eu "humano". Se depender de Stirner, porém, isso não há de ficar assim: Livrando-me agora também do homem, posso finalmente me declarar meu próprio legitimador, meu próprio mediador e meu próprio eu verdadeiro. Meu poder será agora apenas minha propriedade, e me dará minha propriedade sobre o mundo e sobre mim mesmo (UP 237-8, r203). Como começamos a ver, a nova individualidade stirneriana, enquanto proprietária, constitui-se pela negação das três formas de vassalagem modernas acima assinaladas. ${ }^{2}$

Primeiro, sob o título de "Meu Poder", Stirner desenvolve a crítica do direito e da lei - bem como da igualdade que supõem. Como vontade e aprovação "de outrem”, ele é um direito "estranho", que apenas me dão ou permitem (UP 238, r204). Para nosso Único, é a lei que inventa o crime e o criminoso, pois o "eu sem freio" que todos somos só pode ser um criminoso para o Estado $(255, \mathrm{r} 219){ }^{3}$ No lugar do direito - seja ele tradicional, natural ou humano - deve prevalecer "meu poder", ou seja, a força e recurso de cada um (238ss, r204ss). Serei eu o juiz do meu direito (240, 243, r205, 208); o que significaria, em última análise, que "fora de mim não há direito", ou, ainda, que o que tenho força para ser ou fazer a isso tenho direito (242-43, r208). Na verdade, devo riscar do meu vocabulário a palavra direito, pois este se põe acima de mim e sempre supõe um ser superior. "O que eu possuo independentemente da sanção do espírito, eu o possuo sem direito, possuo pela minha força” (266-67, r230-31).

Depois da reapropriação do direito e da soberania como "meu poder" (como uma reversão da alienação no contrato social à la Rousseau, por exemplo), Stirner trata de recuperar "suas relações" como seu intercâmbio ou interação pessoal. Às noções de Povo e

2 Stirner ocupa-se extensamente das três referidas "vassalagens" em três capítulos que tomam quase toda a segunda parte do Único. Como por uma virada dialética, a apropriação se segue ao mais completo despossuimento. É assim também na concepção de Marx, em que o proletariado representa a miséria e a desumanização completas, e ao mesmo tempo a promessa da reapropriação definitiva (SF 47).

3 Aqui também Stirner está tomando a filosofia política moderna ao pé da letra: Hobbes entende que onde não há lei civil não há crime (cf. Leviathan, XXVII), e Espinosa afirma que "o pecado não se pode conceber senão num Estado", (cf. Tratado político, I, § 19).

\begin{tabular}{|l|l|l|l|l|}
\hline Q Ponista Qialectus & Ano 5 & n. 12 & Janeiro - Julho 2018 & p. 163-208 \\
\hline
\end{tabular}




\section{O ANTIPLATONISMO PRÁTICO DE MAX STIRNER... José Crisóstomo de Souza}

Humanidade, mas também ao Estado e ao Partido cristalizado (fixado, burocratizado), ele opõe o primado do indivíduo autônomo, propondo, no lugar daqueles, como vimos, a associação e a revolta. É principalmente aí que ele desenvolve sua crítica à sociedade e à "organização de trabalho", que ele discute a questão social e a propriedade, e volta a tratar do comunismo e do socialismo (UP 267ss, r231ss). Por fim, depois daqueles dois passos, agora sob o título de "minha autofruição", Stirner investe contra a "vocação" (de "homem"), que agora nos é imposta e que ainda hoje impede o indivíduo de viver e gozar sua própria vida.

Com o suposto fim do império opressivo do que são apenas pensamentos nossos, finalmente sem "missão" ou "vocação" prescritas, sem medida ou dever-ser inatingíveis, é que o eu stirneriano - digamos, pós-moderno - poderá fruir de si mesmo. Pois não será convocado a nada além de seu prazer pessoal (UP 401ss, r358ss). Tendo deixado de servir a qualquer Ideia ou Ser superior, tanto quanto a qualquer outro homem de carne e osso, "serei, não só pelo ser e pela ação, mas também pela consciência, único" (499). Tal é o último e grande passo dessa (re-)apropriação, que vai na verdade muito além da recuperação do "meu poder" e de "minhas relações". Pois seria uma recuperação do meu próprio eu, até aqui deslocado pelo Ideal inacessível: "Que é o Ideal senão o eu sempre buscando e jamais atingido?" - Stirner indaga. Para quem ainda se pergunta pelo que deve ser, a vida é apenas uma longa espera, (403, r359-60). Para quem tem uma "vocação" a realizar, a vida de cada um se torna apenas um meio para isso (404, r361). "Se creio ter ainda de descobrir meu verdadeiro eu, estou inteiramente proibido de fruir de mim mesmo" $(403, \mathrm{r} 359)$.

Stirner imagina que, felizmente, estamos (ou já estávamos, no meio do século XIX), pelo menos no Ocidente, na virada de uma época. As pessoas até agora se preocuparam apenas em ganhar a vida (essa ou a outra) e em saber o que devem fazer com ela (UP 401-2, r358). Procuravam dar-se uma destinação exterior a si mesmas, inclusive quando se esforçavam por serem "humanas" e agirem "humanamente". Mas agora, como proprietário e único, sei que não é como homem que me desenvolverei. "Quando me desenvolvo, é a mim que desenvolvo e a nenhuma outra coisa" (450, r406). E agora que não faço nada por amor de um terceiro, o mundo pode finalmente me satisfazer. Para os tipos religiosos, a "imperfeição" do mundo é motivo para desaver-se com ele; quanto a Stirner,

\begin{tabular}{|l|l|l|l|l|}
\hline Q Rovista Dialectus & Ano 5 & n. 12 & Janeiro - Julho 2018 & p. 163-208 \\
\hline
\end{tabular}




\section{O ANTIPLATONISMO PRÁTICO DE MAX STIRNER... \\ José Crisóstomo de Souza}

por "imperfeito" que o mundo seja, ele entende que saberá fazê-lo servir à sua fruição (410, r357-58).

Fruir da vida e de si mesmo é consumi-la e consumir-se (UP 402, r358-59). A flor que desabrocha, alega Max Stirner, não o faz como "missão", mas trata de fruir do mundo, e de "consumi-lo". Também o indivíduo não está chamado a nada, nem tem qualquer destinação mais do que uma flor ou um animal. "Não existe missão a cumprir", nem individual nem coletiva, mas apenas "forças” que desabrocham. Onde existirem, aí elas se manifestarão, pois, "força é apenas uma palavra mais simples para dizer manifestação de força." Não obstante a versão marxiana de que Stirner tem apenas exortações morais para oferecer, este diz agora que as forças estão sempre ativas, e qualquer "ordem de pô-las em ação seria desprovida de sentido". "Empregar suas forças não é vocação ou tarefa", é apenas a vida que não pode ficar inativa. No caso do homem real de carne e osso, ele não é uma meta ou um ideal: “O verdadeiro homem não está no futuro", mas aqui, "quem quer e o que quer que ele seja". Contra o que seria depois o supostamente grande adversário inimigo de velhos e novos Ídolos, Friedrich Nietzsche, para Stirner, há uma enorme diferença "entre me tomar por ponto de partida ou por ponto de chegada": "Se sou minha meta, não me possuo, estou ainda alienado de mim mesmo" (UP 409-11, 366-68). Se já sou o que “devo" ser, posso finalmente fruir da vida e de mim mesmo. Tal é o alcance último da apropriação stirneriana, e esse é o sentido do único e de sua unicidade (450, r406).

Para exorcizar a figura desse indivíduo único, fruidor e consumidor do mundo e de si mesmo, Marx procura exibir o que seria o fundo abstrato do percurso referido (biográfico e histórico), que a ele supostamente conduz. Isso para que a pretensa reconciliação com a própria singularidade e a corporeidade, expressa por Stirner numa linguagem muito pessoal e nada teórica, revele-se como mero disfarce de mais um desenvolvimento filosófico, de tipo hegeliano e especulativo. $\mathrm{Na}$ sua opinião, a segunda metade do Único apenas repete a primeira: depois dos esforços dos antigos (ou da criança) e dos modernos (os liberais humanos) para "soltarem-se" primeiro do mundo das coisas e depois do mundo do espírito, a individualidade própria stirneriana seria tão-somente uma negação/superação daquele "soltar-se”, um soltar-se ao quadrado

\begin{tabular}{|l|l|l|l|l|}
\hline Q Ponista 2 ialectus & Ano 5 & n. 12 & Janeiro - Julho 2018 & p. 163-208 \\
\hline
\end{tabular}




\section{O ANTIPLATONISMO PRÁTICO DE MAX STIRNER...}

José Crisóstomo de Souza

Enquanto proprietária - vejamos agora a mesma coisa, na paráfrase e recapitulação que Marx oferece o percurso stirneriano - tal individualidade constitui-se através de três momentos, por oposição aos três tipos de liberalismo humano ou de libertações. Primeiro, contra o liberalismo político - com o direito, poder do homem, dissolve-se na força enquanto direito do eu, meu. Em seguida, em oposição ao "comunismo", a sociedade que tem como mediador o homem dissolve-se em "relações do eu”. E, finalmente, a “dissolução no interesse do homem”, própria da moderna, ideológica, “Crítica humana" (v.g. Bruno Bauer), dá lugar à "dissolução no interesse do eu”. Nesse processo, cada uma das três expressões da liberdade negativa do liberalismo humano converte-se, uma vez negada, em uma qualidade positiva do indivíduo. Na primeira parte do Único, o "soltar-se" do mundo das coisas e do mundo dos pensamentos já era concebido com apropriação. Agora, no "Novo Testamento" stirneriano, a apropriação das coisas e dos pensamentos não passa ainda de um completo e acabado "soltar-se” (IA 272-74, d222-23).

E o único, fruidor e consumidor? Se, enquanto recupera seus atributos, o eu é proprietário, enquanto frui de si e se consome, entende Marx ironicamente, ele seria simplesmente "proprietário do proprietário", de um lado "senhor" e de outro "solto" de si mesmo. O único seria então, em linguagem hegeliana, absoluta negatividade e relação negativa consigo mesmo (mais ou menos como o Cristianismo). O único teria o mesmo conteúdo do proprietário, e mais a determinação "relação negativa consigo mesmo". Corresponderia, portanto, apenas, Marx quer concluir, a uma individualidade "filosoficamente construída" - como a Ideia ao final da Lógica hegeliana, ou a Personalidade absoluta ao final da Enciclopédia, também de Hegel (IA 274, d233-24). Seria apenas "uma categoria construída com a ajuda do método hegeliano", e não uma individualidade corpórea, conceitualmente inexprimível, como Stirner gostaria (219, d175). Marx trata de refutar aqui a pretensão stirneriana de que o único não pode ser objeto de um "desenvolvimento conceitual", e de que "sua evolução é simplesmente a evolução de cada um" (AC 84-6). A disputa por quem fala em nome - ou a partir - do eu/indivíduo real, concreto, corpóreo, é o campeonato que está sendo jogado, tendo ao final Marx e Stirner como os contendores de sua partida final.

\section{O Indivíduo como Senhor e Medida de Si Mesmo: o Anti-Autoritarismo Prático de Max Stirner}

\begin{tabular}{|l|l|l|l|l|}
\hline Qovista Dialectus & Ano 5 & n. 12 & Janeiro - Julho 2018 & p. 163-208 \\
\hline
\end{tabular}




\section{O ANTIPLATONISMO PRÁTICO DE MAX STIRNER... \\ José Crisóstomo de Souza}

Com efeito, segundo Stirner, o Cristianismo tem sido no Ocidente o grande adversário do reconhecimento do indivíduo verdadeiramente - corporeamente - singular na sua unicidade. O Cristianismo - diz nosso proto-Nietzsche anti-aristocrático - despreza o que é estritamente próprio (eigen), como no caso do interesse egoísta (Eigennutz), do amor de si (Eigenliebe), da teimosia (Eigensinn) (UP 219-20, r186-87) ${ }^{1}$ - termos todos esses de conotação negativa. A lição do Cristianismo seria a liberdade, que, como puro "soltar-se" ou "desprender-se de", quer o indivíduo livre inclusive de si mesmo. A ela Stirner opõe a individualidade (Eigenheit), que assume tudo que me/lhe é "próprio", e da qual tudo depende (221, r188). A liberdade, que representa no máximo uma permissão, não tem conteúdo algum, e só ofereceria alguma coisa a quem souber valer-se dela. ${ }^{2}$ Mais do que livre, é preciso ser primeiro "dono" (Eigner), do contrário a busca mesma da liberdade acabará por conduzir a uma abnegação, a uma negação de si mesmo (203-4, r171-72).

Stirner está falando agora com os filósofos políticos modernos, iluministas, alguns dos quais chegam a pôr a questão do ser dono de si, mas de um modo ao que parece inteiramente insatisfatório. A liberdade proposta por eles significa ainda e sempre a obediência a outra coisa como a si mesmo, à Razão (Espinosa), à "Regra comum" (Locke), ou à "Vontade geral" (Rousseau) - esta última, capaz até de obrigar o indivíduo a ser livre. Bruno Bauer, por fim, procuraria fazer a defesa da Liberdade pura e verdadeira, em oposição a qualquer liberdade "fixada" num Estado ou Sociedade. Stirner, porém, repudia o culto da liberdade e desconfia em especial das promessas de liberdade infinita. Segundo ele, a liberdade jamais se tornará minha sob a forma de liberdade. ${ }^{4}$ Sua aquisição sendo um processo infinito, haverá sempre algo de que me libertar, como também coisas de que

1 Stirner entende que a influência do Cristianismo sobre a linguagem transformou também o significado de palavras alemãs como Schimpf (de "brincadeira" para "insulto"), Frevel (de "audácia" para "delito"), Frech (de "bravo" para "insolente"). (UP 219-20; r186-87).

2 Marx parece aproximar-se da ideia de Stirner quando entende que a liberdade do homem não está "na força negativa de evitar algo", mas "na força positiva de fazer valer a verdadeira individualidade" (SF 157-58). Só que aparentemente essa individualidade, devendo ser "verdadeira", há de coincidir como sua "essência" - humana, genérica, social

3 Cf. Espinosa: "Um homem é senhor de si próprio sobretudo quanto mais vive sob a conduta da Razão". (Espinosa, Tratado político, vol.1); e "possuem-se a si mesmos no mais alto grau" aqueles em que ela domina (ibid., v.II, 11).

4 A cultura, a religião e a ciência, segundo Stirner, libertaram os homens de muitas coisas, e tornaram o eu em algo "poderoso" - pelo menos potencialmente. Faltaria agora pôr um fim à potência da própria cultura - ou espírito - sobre o indivíduo (UP 416-17, r373-74).

\begin{tabular}{|c|c|c|c|c|}
\hline Qevista Dialectus & Ano 5 & n. 12 & Janeiro - Julho 2018 & p. $163-208$ \\
\hline
\end{tabular}




\section{O ANTIPLATONISMO PRÁTICO DE MAX STIRNER... José Crisóstomo de Souza}

absolutamente não quererei me ver livre. A liberdade completa e infinita representa então mais um um fantasma e um ideal inatingível (UP 204-6, r172-73) - um Ídolo.

Ora, se é assim com o "ser-livre-de", para Stirner, com o "ser si mesmo" e "de si mesmo" tudo seria diferente. A individualidade ou ser próprio já é ao mesmo tempo minha essência e minha existência. Sou sempre eu próprio e de mim próprio - desde que decida "não me aviltar" diante de algo concebido como Superior. Mesmo diante de cadeias impostas pela realidade, posso permanecer de mim mesmo e não me perder de vista (UP 206, r173-74). O que não significaria contentar-se com algum tipo de liberdade "em si” ou “interior" que não me livra do chicote do senhor. A diferença entre a liberdade e a individualidade é mais profunda, e o que está em jogo se poderia talvez chamar de opção pelo eu.

O sonho cristão de um reino da liberdade - em que, como na concepção de Marx, os homens não encontrarão uma barreira nem mesmo nos outros - seria para Stirner absolutamente irrealizável (UP 206-7, r174-75), além de indesejável. E, ainda para ele, a luta por uma liberdade determinada teria até aqui conduzido sempre a uma nova dominação, como a da lei. No entanto, em ambos os casos, prossegue, poder-se-ia perceber que as pessoas querem livrar-se sempre daquilo que está em seu caminho, jamais daquilo que lhes agrada - e sempre, admitamos, "por seu próprio bem". Ou seja, mesmo quando lutam pela liberdade, seria a si mesmas que as pessoas tomam tacitamente como "medida" e "juiz". Por que, então, propõe Stirner, não fazerem logo e expressamente de si mesmas o “centro" e o "principal" em vez de terem em vista um "sonho" ou um "pensamento"? "A liberdade é um sonho, você não!” Portanto, “descubra o que está em você mesmo”, "revelese", saiba o que você quer! (207-10, r175-78, passim). Quanto a isso, as pessoas ainda prefeririam consultar Deus, a Sociedade ou a Consciência, a ouvirem seu próprio eu, diz Stirner (210, r177-78). Eles imaginam-se como "um poço de desejos e apetites" perversos, e acreditam que seguir este eu significaria enveredar pelas piores loucuras. "O hábito de pensar religiosamente deformou tanto o nosso espírito que nossa nudez e nosso natural nos apavoram" - embora o animal, que segue apenas o próprio instinto, na verdade não cometa nenhum desatino $(211, \mathrm{r} 178)$.

Já seria hora de indagar, Stirner propõe modesta e investigativamente, se Deus, Consciência etc., não foram histórias que deformaram profundamente nossos corações e

\begin{tabular}{|l|l|l|l|l|}
\hline Q Rovista Dialectus & Ano 5 & n. 12 & Janeiro - Julho 2018 & p. 163-208 \\
\hline
\end{tabular}




\section{O ANTIPLATONISMO PRÁTICO DE MAX STIRNER... José Crisóstomo de Souza}

mentes (UP 211, r178-79). E talvez reconhecer que é ainda por seu próprio bem e por sua própria salvação que o indivíduo se preocupa com os mandamentos de Deus ou quaisquer outros. Do mesmo modo que, se os indivíduos querem ver-se livres de tudo, menos de si próprios, o que restará será sempre o eu de cada um, ao qual a liberdade nada terá a dizer (212-13, r179-80). Eu não sou, como a liberdade, uma coisa por vir; já estou aqui. Por que, então, não me tomar logo como o começo, o meio e o fim? Pois a liberdade não te conduz a ti, apenas “atiça a cólera contra tudo o que não é tu mesmo.” A liberdade prescreve o livrarse de tudo, a individualidade simplesmente te convida: "Vem para ti mesmo!", pois como próprio você já está realmente livre de tudo" (213-14, r180-81).

Stirner contrapõe sua unicidade à generalidade do "homem" dos filósofos, do mesmo modo que opõe à liberdade, enquanto "soltar-se de", à individualidade enquanto um não apartar-se de si. É quando se reconhece como único que o indivíduo se torna efetivamente proprietário de seu poder e de suas qualidades, que se assume como criador mortal de sua própria causa (UP 456, r 412), que se torna ativo e se desenvolve (450, r406). ${ }^{5}$ É como único (mas, note-se bem, não necessariamente como oposto ao humano o ao desinteressado) que o egoísta representa a superação da oposição "humano-desumano" (195, r162). A teoria crítica de Bruno Bauer entende que os homens comuns constituem uma multidão de "egoístas" e "não-homens". Com o que, Stirner conclui, o não-humano é o real que está em toda parte, e o homem dos filósofos é o que não está em parte alguma (193-94, r160-61). ${ }^{6}$ Desde o advento do Cristianismo - que na verdade reconheceria apenas um único homem como verdadeiro cristão, Cristo - só teriam existido não-homens. Hoje, porém, depois de reduzir o homem a uma simples propriedade minha, não sou mais um não-homem, sou único (228-29, r194-95). Só sou inumano para quem me opõe ao humano; e é essa oposição que me bane de mim e me faz desprezar-me a mim mesmo. Agora, como individualidade única, como me ser próprio, "deixo de me medir pelo homem" e de reconhecer qualquer Ser Supremo (194-95, r161-62). Desse modo romper-se-ia finalmente

5 "Não é enquanto homem que me desenvolvo, e não é o homem que desenvolvo em mim, tal é o sentido do único" (UP 450, r406).

6 Esse binômio, humano-inumano, ao qual tratará de dar um conteúdo "empírico" na Ideologia alemã, Marx ainda utilizava expressamente na Sagrada família. Aí o proletariado é a "humanidade consciente de sua desumanidade", é a condenação do "não-humano" da sociedade (SF 47).

\begin{tabular}{|l|l|l|l|l|}
\hline Qonista Dialectus & Ano 5 & n. 12 & Janeiro - Julho 2018 & p. 163-208 \\
\hline
\end{tabular}




\section{O ANTIPLATONISMO PRÁTICO DE MAX STIRNER... José Crisóstomo de Souza}

o "círculo mágico do Cristianismo", e resolver-se-ia pôr fim a contradição entre existência e essência, entre existência e vocação, entre eu como sou e eu como deveria ser.

Enquanto o cristão e o idealista imaginam como meta a realização ou corporificação da Ideia (ou do Ideal), como o fim dos tempos ou a meta da História, o único quer ser a solução presente para tudo isso. Para o cristão, o indivíduo deve "participar na construção do Reino", para o liberal humanista, deve participar do desenvolvimento da História. Já o indivíduo único não reconhece semelhante missão, nem imagina estar no mundo para realizar qualquer ideal. Quer apenas desenvolver-se, e não à ideia de Humanidade ou qualquer outra Ideia. Entende que o ideal de homem está realizado quando chegamos à sentença: "Eu, este único, sou o homem". Com isso, a questão conceitual: Que é o homem? transforma-se na questão pessoal: Quem é o homem? cuja resposta está dada pessoalmente naquele que indaga. Pois "nenhum conceito me exprime", e "nada do que se aponta como minha essência me esgota" (UP 455-56, r410-12).

Quem é então o único finalmente? Stirner nos dirá de forma quase apaziguadora: "Você é único". O único representaria o último dos predicados, "a expressão que não é expressão" pois tem como conteúdo apenas você, que é o impensável e o conceitualmente inexprimível. ${ }^{7}$ Não se tratando do quê, mas de quem, aí a ciência e a filosofia desembocam finalmente na vida; "isso torna-se esse, e mais esse aqui, que não poderão mais ser abrigados numa palavra ou predicado" (AC 92-3). Segundo Stirner, embora muitos pretendam (como, para ele, Feuerbach, Bauer e o próprio Marx) falar do homem singular, este não pode ser expresso por uma generalidade ou um predicado, por uma teoria, como homem de carne e osso. Pois o único não tem definição, é uma total ausência de determinação, um "conceito" cujo conteúdo encontra-se fora do mundo conceitual. Não seria um novo princípio, sobre o qual se pudesse construir um sistema filosófico, nem é um conceito indeterminado que possa receber determinação através de outros conceitos. Ele é incapaz de todo desenvolvimento conceitual pois seu desenvolvimento ou teu desenvolvimento é diferente de qualquer outro. No único se encerraria finalmente para Stirner o império dos pensamentos absolutos e ficaria para sempre aniquilado - ou melhor, desinflado, o mundo do conceito (AC 86-87).

7 Feuerbach diz que "a impossibilidade de dizer o singular refuta a linguagem, não o singular" (CFH 37-8).

\begin{tabular}{|l|l|l|l|l|}
\hline Qevista Qialectus & Ano 5 & n. 12 & Janeiro - Julho 2018 & p. 163-208 \\
\hline
\end{tabular}




\section{O ANTIPLATONISMO PRÁTICO DE MAX STIRNER... José Crisóstomo de Souza}

A unicidade do eu stirneriano significa que ele não representa apenas mais um eu ao lado de outros. O serem todos eus não quer dizer uma nova igualdade, mas uma diferença que cria entre eles uma forma aguda, radical, de oposição. Quando se quer "dissolver" a oposição entre os homens, em geral se procura emprestar-lhe um sentido fraco, "para dar lugar a um termo conciliador". Para nosso agonístico Max Stirner, ao contrário, seria antes o caso de acentuar mais a oposição. Um judeu e um cristão, por exemplo, diz ele, ainda não estariam opostos de maneira bastante radical, pois seriam ainda iguais quanto ao resto. Como tal resto na verdade é sempre inteiramente diferente, em vez de o dissimularem deveriam antes reconhecer sua completa oposição como unicidade. Só assim a teriam resolvido, pois uma oposição mais forte teria absorvido em si a oposição anterior (UP 264-65, r228-29).

Em total contraste com Marx, Stirner acredita que o problema do mundo moderno não resulta de os homens estarem opostos uns aos outros, mas de não o estarem da forma mais completa. Sua (deles) fraqueza reside em não estarem ainda inteiramente separados, em buscarem ainda uma absoluta comun-idade. Apesar disso, a última e mais radical oposição proposta por Stirner, a dos indivíduos enquanto únicos, pretende ultrapassar tudo o que se entende por oposição, "sem recair na unidade e na concórdia". "Enquanto único, você não tem mais nada de comum com o outro, e, por isso mesmo, tampouco nada de divisão ou de hostilidade”. Entre outras coisas, você agora não procura, contra ele, a autoridade absoluta de um Terceiro" (UP 265, r229) - existente ou abstrato.

Os indivíduos stirnerianos radicalmente opostos e distintos não se tratariam entre si como homens, mas como egoístas. O que representaria o fim da Sociedade humana e do Estado sagrado (que precisam do homem e da moralidade, que tomam ao homem como fundamento), para dar finamente lugar a uma reunião de eus conscientes de si (UP 230-31, r196). Stirner diz que não pretende que sua oposição egoísta ao Estado represente o ponto de vista do mercado ou sociedade civil (como entenderiam seus críticos comunistas Hess e Marx), o qual deveria então se expandi para absorver o Estado e a família. Para ele, nem esta última corresponde ao espaço do desinteresse, nem a sociedade civil representa o terreno do egoísmo - apesar de ser assim para Hegel e para os adeptos da Sociedade humana. O conteúdo da sociedade civil, de acordo com Stirner, é a "vida de negócios",

\begin{tabular}{|l|l|l|l|l|}
\hline Q Rovista Dialectus & Ano 5 & n. 12 & Janeiro - Julho 2018 & p. 163-208 \\
\hline
\end{tabular}




\section{O ANTIPLATONISMO PRÁTICO DE MAX STIRNER... José Crisóstomo de Souza}

ainda largamente determinada pelo "sagrado" ${ }^{8}$ (AC 160-61) - não seria seu ideal nem sua referência

Mesmo assim, diz Stirner, o egoísmo não seria inteiramente uma novidade, ele sempre de algum modo orientou o comportamento dos homens (UP 212-13, r179-80). O egoísmo stirneriano é antes de mais nada a afirmação desse ser-de-si-mesmo a que ninguém escaparia, mesmo pela via tortuosa e contraditória da abnegação. Só que séculos de cultura cristã nos teriam afastado de nós mesmos, e agora tornar-se egoísta (tornar-se "um eu todopoderoso") é principalmente retomar conhecimento de si mesmo como centro e medida. É chegada a hora de abandonar a hipocrisia e a insensatez de ser outra coisa $(214, \mathrm{r} 180) .{ }^{9}$ Durante séculos os indivíduos têm sido egoístas adormecidos e incompletos, que iludem e torturam a si mesmos. A própria religião fundar-se-ia sobre egoísmo, mas aí o egoísta satisfaria apenas um de seus apetites (a sede de beatitude, por exemplo), e não a si mesmo. Em tal caso, teríamos o egoísmo inconfesso, parcial e inconsciente, que é antes servidão e negação de si (214-15, r181-82).

Esse egoísmo, assim entendido, embora incompleto, seria o que está em toda parte. Não é o homem que é universal, mas eu e o egoísmo, pois, no fundo, "todo mundo é um egoísta e se coloca acima de tudo" (UP 232, r198). Tanto Marx como Bruno Bauer, a propósito da chamada questão judaica, opõem a universalidade do homem à limitação e ao egoísmo do ser judeu ou cristão. Stirner lhes opõe o egoísta sem peias que todos no íntimo seríamos. O judeu e o cristão seriam apenas egoístas pela metade ("metade proprietários e metade escravos”). Satisfariam só alguns de seus desejos e não a si mesmos, bem como excluir-se-iam entre si pela metade: como escravos de diferentes senhores. Se fossem completamente egoístas, acha Stirner, eles se excluiriam totalmente e, por isso mesmo, paradoxalmente estariam mais juntos (232-33, r198). O homem dos filósofos, ao contrário, é somente um suposto universal, que além de não passar de uma quimera, exclui o egoísta ou seja, na verdade, exclui o indivíduo todo e todos os indivíduos.

8 Essa alegação de Stirner pode fazer sentido, quando se pensa na moral (mesmo se julgada hipócrita) da sociedade civil burguesa, no direito civil burguês e nas novas dependências e feudalismos em que se baseia. E quando se recorda que, na concepção stirneriana, o egoísmo opõe-se à fixação dos desejos, quer sobre objetos espirituais, quer materiais, e convida à plena fruição de si mesmo e ao ócio, tanto quanto ao neg-ócio.

9 "Queremos nos tornar aquilo que somos" - diz Nietzsche na Gaia ciência, § 335, num trecho de aparente ressonância stirneriana. Também para Nietzsche isso deve significar tornarmo-nos "únicos" e "incomparáveis", "legisladores" e "criadores" de nós mesmos.

\begin{tabular}{|l|l|l|l|l|}
\hline Qevista Dialectus & Ano 5 & n. 12 & Janeiro - Julho 2018 & p. 163-208 \\
\hline
\end{tabular}




\section{O ANTIPLATONISMO PRÁTICO DE MAX STIRNER... José Crisóstomo de Souza}

Os humanistas de todo tipo horrorizam-se diante do egoísta como se este fosse o diabo, mas o egoísta deles, este sim, para Max Stirner, não é mais do que uma "assombração", que resulta da sobrevivência de uma velha antítese entre "bem" e "mal" (UP 448). Seu egoísta é a nova versão do pecador, e todos os homens são para ele egoístas, tal como antes eram todos pecadores. A ideia de vencer o egoísmo e realizar o homem verdadeiro procuraria medir os homens com um conceito, e levaria a repudiar o que neles “é diferente e único", ou seja, a repudiar os indivíduos tais como são e podem ser. (AC 12021).

\section{Finalmente o Indivíduo de Carne e Osso. O Virtuoso Egoísmo Stirneriano como Crítica Própria e Desejante.}

Em sua oposição ao egoísmo, o homem moderno dos filósofos representa o ideal-espiritual, apenas sob nova feição. Os mais recentes modernos, mesmo repudiando os dogmas da igreja ou a imortalidade da alma, continuariam a defender que "o espiritual", o "ideal”, o "teórico", que devem prevalecer sobre o resto todo. Ora, esse resto é o egoísmo, e é egoísta quem não vive para algo de "espiritual" - que não sacrifica seu interesse pessoal por uma Ideia. Ao fim e ao cabo - para os mais "espiritualizados" - gozar de um privilégio, por exemplo, seria pecar contra a ideia de igualdade, dominar de alguma maneira um outro sempre seria pecar contra a ideia de liberdade, e assim por diante. Em oposição a isso, porém, egoísta stirneriano, não quer ser um materialista grosseiro, mas apenas subordinar esse "espiritual" - tanto quanto o material - ao pessoal, e não proibir-se de se ocupar de si mesmo e do que lhe interessa. Ele faz de si o centro, e busca seus interesses (materiais ou espirituais), tanto quanto seus laços ou mesmo devoções, por seu prazer - isto é, como seus. Os críticos do egoísmo, pretendendo censurar quem não tem quaisquer interesses espirituais, acabariam na verdade repudiando os que não põem esses interesses acima de si mesmos, como abnegados (UP 57-8, r31-2).

Stirner prefere mostrar que, paradoxalmente, tanto o egoísta "em sentido vulgar" quanto o chamado idealista "religioso" sacrificam-se e se negam; não sendo, portanto, nenhum dos dois, egoístas em sentido stirneriano. Sacrificar-se é subordinar-se a uma paixão ou objetivo, seja material ou espiritual, o que pode ser tanto o caso do usurário, que se priva de tudo para acumular, quanto o do apaixonado, que enfrenta perigos e

\begin{tabular}{|l|l|l|l|l|}
\hline Q Povista Dialectus & Ano 5 & n. 12 & Janeiro - Julho 2018 & p. 163-208 \\
\hline
\end{tabular}




\section{O ANTIPLATONISMO PRÁTICO DE MAX STIRNER... \\ José Crisóstomo de Souza}

privações por seu amor. Por outro lado, sendo ambos "possuídos", isso não os impede de serem também, ainda assim, egoístas, e de toda maneira, interessados (UP 110, r81-2). Também os supostos desinteressados, que se sacrificam e se interessam apenas pela liberdade, pela humanidade, ou por qualquer outro Ideal, não seriam, para Stirner, menos egoístas - embora por certo sejam egoístas incompletos, enviesados, disfarçados. Alguém dirá que seu interesse é humano e geral, comprometido com uma ideia e não com simples indivíduos. No entanto, trata-se sempre de sua ideia - de liberdade, de homem, de justiça, do que seja. (169, r138). O suposto desinteressado é então simplesmente aquele que tem um interesse ideal diante do qual nada mais interessa.

A posição de Stirner tem algo de uma "personalização" dos valores (ou ideais), de sua remissão ao sujeito que os sustenta, mais do que de uma negação pura e simples dos mesmos. Seu egoísmo, por outro lado, não quer significar um isolamento, um "pensar apenas em si", ou um deixar de perceber que o outro, a quem trata como propriedade, pertence igualmente a si mesmo (AC 128, 130). No amor, por exemplo, o amante pode "esquecer-se" de si, só que isso seria ainda uma maneira de satisfazer-se e de fruir de sua "propriedade". Esquecer de que se é o proprietário e o centro, considerar algo como superior e sagrado em si e por si, isso sim seria diferente. Neste caso, teríamos a abnegação, que representa o "egoísmo servil" e "sem coragem" que se desconhece e que se nega (98100). O egoísta stirneriano, diz o próprio Stirner, não é alguém que pensa apenas em si mesmo, pois tal pessoa seria na verdade um indivíduo "pobre", privado de muitos prazeres. Seria um indivíduo que não só tem interesse pelos outros, como também procura conquistar o interesse desses - o que, porém, seria bem diferente do cultivo do amor como obrigação. Como oposto ao desinteresse, o egoísmo não quer ser o contrário do amor, a negação do socialismo ou a exclusão de qualquer interesse real. Ele só repudia a "ausência de interesse" e o que é "desinteressante” (131-32).

A crer em Stirner, seu egoísta é ainda um "homem comum" - no lugar, por exemplo, do "homem comunitário" do altruísta Feuerbach (AC 120). Tal egoísta vê o mundo, como não poderia deixar de ser, a partir de si mesmo, e vive de certo odo dentro do seu mundo, coisa a que ninguém escaparia (98). Mas não é um ser humano desinteressado, nem um ser humano sem outros interesses que não ele mesmo; o interesse geral "sagrado", "religioso" - é que não the diz respeito. Pois é um interesse "em si", um

\begin{tabular}{|l|l|l|l|l|}
\hline Qevista Dialectus & Ano 5 & n. 12 & Janeiro - Julho 2018 & p. 163-208 \\
\hline
\end{tabular}




\section{O ANTIPLATONISMO PRÁTICO DE MAX STIRNER... José Crisóstomo de Souza}

interesse "sem sujeito" - que exige servidores e se afirma em oposição ao interesse de cada um (AC 106). O interesse geral - sempre oposto a todo interesse privado - seria apenas o princípio abstrato, alienado, tanto da moral humana quanto do socialismo e comunismo sagrados".

A relação com algo "absolutamente interessante" ou "valioso por si" é, segundo Stirner, uma relação ainda religiosa. Pois algo só poderia ser interessante por teu interesse, e nada seria valioso "apesar de ti” (AC 104). O egoísta stirneriano, enfim, é alguém que não alimenta qualquer interesse absoluto, em si, que a ele se imponha como um dever-ser ou algo de sagrado. A "sociedade humana", por exemplo, como "sociedade universal", quer conquistar e ungir defensores - na verdade, porém, seus "socialistas santos" entravariam o relacionamento direto e ordinário entre os indivíduos ordinários, e impediriam, como os demais "tipos religiosos", que eles sejam finalmente reconhecidos e apreciados (122).

Terá o egoísmo stirneriano a pretensão de ser uma nova crítica, finalmente o ponto de vista verdadeiramente crítico? Não, diria Stirner, enquanto toda crítica estaria inextricavelmente presa ao mundo do pensamento, dos conceitos, da teoria, e seria, em última análise, dogmática: "Mesmo a crítica que arruína todos os princípios estabelecidos ainda crê decididamente num princípio" (UP 436, r393). Os “críticos” diferiram entre si segundo o critério que adotam, mas buscariam sempre o critério justo, superior, através do qual dividem tudo em duas classes: bom e mau, humano e desumano. O critério absolutamente justo seria o segredo e a pressuposição de toda crítica - a crença do crítico. Mesmo quando tal pressuposto de um modo geral é simplesmente uma ideia tomada do espírito da época e considerada como óbvia, como no caso da liberdade ou da humanidade dos filósofos do Esclarecimento. Por trás do crítico, então, estaria sempre um dogmático (346-47, r393). ${ }^{10}$ Toda crítica parte sempre de uma crença e é exercida por amor de uma essência ou princípio qualquer, que o crítico entende possuir, e que imagina deva possuir também aos outros (UP 437, r394).

O crítico busca a verdade como critério, só que esta, para Stirner, é apenas o pensamento que se apresenta como superior e irrecusável, o pensamento impessoal, que

10 Não é à toa que Marx trata de dizer que seus pressupostos - a partir dos quais ficaria condenado o egoísmo da propriedade privada e da divisão do trabalho - são os indivíduos reais, que estabelecem entre si relações, cuja sucessão conduzirá ao que já sabemos. Nesse caso, segundo ele, seriam pressupostos que ninguém pode deixar de reconhecer salvo na imaginação.

\begin{tabular}{|l|l|l|l|l|}
\hline Revista Dialectus & Ano 5 & n. 12 & Janeiro - Julho 2018 & p. 163-208 \\
\hline
\end{tabular}




\section{O ANTIPLATONISMO PRÁTICO DE MAX STIRNER... José Crisóstomo de Souza}

quer ser livre com relação a ti, embora só exista na tua cabeça. Ora, quem busca a verdade procuraria exatamente um "Senhor" para dele se tornar servo. Como é o caso do homem religioso, "que não crê em si mesmo", mas em outra coisa. "Pois a potência da verdade é tua impotência, e sua humilhação é tua elevação". "A verdade de um pensamento é a sua potência sobre o indivíduo" (UP 440-41, r396-98) - o Único conclui.

O fundamento ou medida que a crítica toma como algo sólido seria apenas a afirmação prévia de um determinado pensamento, um pressuposto, como primeiro em relação a qualquer outro. É um pensamento fixado, uma ideia fixa, um dogma a partir do qual vai-se pensar, medir e criticar tudo mais (UP 438, r394), sem que ele próprio seja criticado. Ora, quem acredita em tal soberania do pensamento e quer promover o seu domínio seria no fundo justamente um "cristão" - pois, mesmo combatendo ou destruindo as ideias dominantes, tende sempre a estabelecer um pensamento, uma ideia, um ideal, como novo princípio ou verdade superior, transcendental, para o seu lugar. Mas, enquanto durarem essas verdades a que os homens devam servir, esses continuarão escravos do "espírito" e do "sagrado" da religião (435, r391). Enquanto for assim, a hierarquia sobreviverá, e a palavra estará dada aos sacerdotes, políticos e professores, gente como Proudhon, Georges Sand, Robespierre, Saint-Juste etc. (436, r393) - aos filósofos, aos intelectuais, ao homem teórico, do espírito.

No entanto, nenhum pensamento, de acordo com Stirner, pode ser o primeiro começo. "Se o pensamento realmente começasse, em lugar de ser começado, ele seria um sujeito dotado de atividade própria". Como no sistema hegeliano, em que o pensamento é capaz de pensar e de agir, de desenvolver a si mesmo; ou como no caso da crítica baueriana, que entende que pelo pensamento faz e acontece. Nesse caso, o pensamento não aparece como o que de fato é, uma propriedade minha, mas como algo "por si" - algo hipostasiado. Ora, o pensamento não tem como pressuposto o pensamento em geral, nem um pensamento qualquer em particular, mas apenas a mim, que o penso. Antes que o pensar ou um pensamento seja, “eu [que o penso] sou” (UP 438-39, r394-95). ${ }^{14}$

${ }^{14}$ Stirner não poderia ser mais claro, mas, mesmo assim Pierre Naville é capaz de entender que "ele afirma que o pensamento é seu próprio pressuposto, isto é, que o pensamento não tem pressuposto". Pierre Naville, De l'aliénation à la jouissance, p.282.

\begin{tabular}{|l|l|l|l|l|}
\hline Revista Qialectus & Ano 5 & n. 12 & Janeiro - Julho 2018 & p. 163-208 \\
\hline
\end{tabular}




\section{O ANTIPLATONISMO PRÁTICO DE MAX STIRNER... José Crisóstomo de Souza}

Tais considerações estariam prenhes de consequências práticas. Pois agora sou inevitavelmente eu - e não qualquer pensamento - a medida das coisas. ${ }^{15} \mathrm{O}$ crítico servil, baseado em seu princípio dogmático, “sacrifica falsos deuses ao seu deus verdadeiro”. Já o egoísta único, mesmo quando critica, não tem sequer a si mesmo diante dos olhos, mas apenas procura "seu prazer" (UP 439, r396). O crítico servil tem no pensamento seu critério; já a "crítica própria", de Stirner, aproximar-se-ia, segundo ele mesmo, da "crítica animal do instinto". Para esse "crítico próprio", o critério sou eu enquanto "indizível” e “impensável” - eu e meu agrado, eu enquanto corpóreo. Desse ponto de vista, verdadeiro é o que é meu, e falso tudo aquilo que quer fazer de mim sua propriedade - seja o Pensamento, o Estado ou a Sociedade (443-44, r400). Isso assumido confessadamente resultaria até numa certa modéstia, por ser a admissão da própria finitude de que se tem consciência, e da finitude do seu pensamento, numa atitude que não invoca qualquer Autoridade transcendental para o que é apenas seu.

Sou certamente um indivíduo insignificante, Stirner admite, mas para mim não há verdades ou princípios independentes de mim mesmo, pois "acima de mim não há nada" (UP 442-43, r399). Já o crítico livre, ou verdadeiro, critico puro ou crítico críeitoc, jamais se livrará do mundo das ideias, enquanto imaginar que existe algo superior ao indivíduocorpo, de carne e osso (444, r400). Pois “é apenas através de 'carne' que posso romper a tirania do Espírito" (96, r68). Esse crítico servil (como mesmo o "Crítico Livre" - à la Bruno Bauer) pretende conferir realidade a uma ideia, só que é justamente como minha que ela pode ser real, é em mim - e em você como outro eu - que ela encontra sua realidade. "Sou sua realidade", pois sou eu, enquanto corpóreo, que a tenho, que tenho a ideia (44445, r401). Por isso Stirner entende que o que expressa com seu novo ponto de vista não é nenhuma força do pensar, mas finalmente "a força da ausência do pensar." Não se trata de um trabalho de dissolução levado a cabo pela Crítica ou pela Autoconsciência, sempre do Pensamento, como para o típico filósofo, o típico hegeliano ou mesmo o típico platônico. "Mas o trabalho do arbítrio, que não faz caso do reflexivo pensar" (AC 114).

Uma consequência prática dessa postura é que a "salvação do mundo" não fica na dependência da casta dos indivíduos pensantes, os filósofos ou os intelectuais, homens

15 Não é preciso dizer que, com seus pressupostos “empíricos” irrecusáveis, as "consequências práticas” de Marx são bem outras.

\begin{tabular}{|c|c|c|c|c|}
\hline Q Rovista Dialectus & Ano 5 & n. 12 & Janeiro - Julho 2018 & p. $163-208$ \\
\hline
\end{tabular}




\section{O ANTIPLATONISMO PRÁTICO DE MAX STIRNER... José Crisóstomo de Souza}

do espírito. Um pensar crítico - desde que se faça próprio e egoísta - pode, segundo Stirner, ser uma via de libertação do domínio das ideias e preconceitos. Para os que têm uma inclinação pensante, o próprio livro $O$ Único e sua propriedade pode representar justamente um tal percurso. Mas mesmo esse livro trata de mostrar que também um salto ou um berro ou um dar de ombros podem fazer o mesmo efeito (AC 114-16). "Não é o pensar que me pode salvar da possessão, mas minha ausência de pensamento". Um dar de ombros ou um esticar o corpo podem vencer o "tormento das ideias". Um pulo pode "derrubar o castelo do mundo religioso" - ou teórico. E "um berro de alegria" pode livra-me de todo o seu peso. A ideia de que só através de um pensamento crítico posso me livrar dos dogmas seria para Stirner exatamente mais um dogma; do mesmo modo que tratar o "não-pensar", como é o caso de Bruno Bauer, como "preguiça egoísta da massa" (AC 110). "A formidável importância da alegria sem pensamento", diz Stirner, não pôde até aqui ser reconhecida "na longa noite do pensamento e da crença" (UP 197, r164).

A audaciosa - e extrema - proposta do "não-pensar" do Único parece pôr em xeque suas concorrentes contemporâneas, dos demais jovens-hegelianos, do tempo em que o livro foi escrito, na incessante busca de se superarem uns aos outros em radicalidade e ateísmo, uma busca supostamente empenhada em recuperar finalmente para a filosofia, ou para além dela, a plena concretude do humano, material, corpóreo. Marx não quis reconhecer nesse empenho stirneriano nada de novo e digno de atenção, embora pareça ter se sentido atingido pela agudeza do desafio stirneriano. Mesmo hoje, até autores que parecem participar de um pathos de "radicalização hiperbólica"16 da esquerda hegeliana, esforçam-se por levantar a bandeira da Crítica e do Pensamento Crítico sem maior consideração pelas ressalvas do esquecido Max Stirner. Gilles Deleuze, por exemplo, empenha-se por atribuir a Nietzsche nada menos que o título de "Crítico verdadeiro". ${ }^{17}$ Para ele, o autor de Zaratustra, cujo pensamento deveria ser preservado contra amálgamas que representam "perigos para o espírito" (!), quer precisamente "libertar o pensamento"(!). ${ }^{18}$ Apenas o pós-moderno Jean-François Lyotard parece ter em conta Stirner quando advoga que "a relação crítica ainda se inscreve na esfera do conhecimento e da tomada de

16 A expressão é de Ferry \& Renault, in: Pensamento 68: ensaio sobre o anti-humanismo contemporâneo, para se referir ao "anti-humanismo" francês mais recente.

17 Cf. Gilles Deleuze, Nietzsche et la philosophie, p. 225.

18 Ibidem, p.223.

\begin{tabular}{|l|l|l|l|l|}
\hline Qevista Dialectus & Ano 5 & n. 12 & Janeiro - Julho 2018 & p. 163-208 \\
\hline
\end{tabular}




\section{O ANTIPLATONISMO PRÁTICO DE MAX STIRNER... José Crisóstomo de Souza}

Consciência". E quando caracteriza a Crítica como fundamentalmente conservadora, defensora de um novo status quo fixado. Em vez de crítica, Lyotard acredita (aparentemente como Stirner) que é "o derivar do desejo" que destrói progressivamente a ordem atual. ${ }^{19}$ Melhor, em todo caso, ler o próprio Stirner.

\section{REFERÊNCIA:}

CORNU, Auguste. Carlos Marx \& Federico Engels. V. 4. La Habana: Editora de Ciencias Sociales, 1975.

DE SOUZA, José Crisóstomo. A questão da individualidade: a crítica do humano e do social na polêmica Stirner-Marx. São Paulo: Editora da UNICAMP, 1993.

DE SOUZA, José Crisóstomo. Ascensão e queda do sujeito no movimento jovem hegeliano. Salvador: Editora da UFBA, 1992.

DELEUZE, Gilles. Nietzsche et la philosophie. Paris: Presses Universitaires de France, 1970.

ESPINOSA, Baruch de. Tratado político. In: Espinosa (Col. Os Pensadores). São Paulo: Abril Cultural, 1983, p. 303-66.

FERRY, L. e RENAUT, A. Pensamento 68: ensaio sobre o anti-humanismo contemporâneo. São Paulo: Editora Ensaio, 1988.

FEUERBACH, Ludwig. "Contribution à la Critique de la Philosophie de Hegel." In Manifestes philosophiques: textes choisis (1839-1845). Paris: Presses Universitaries de France, 1960, p. 11-56.

HESS, Moses. "Die letzten Philosophen." (Os Últimos Filósofos). In: Löwith, Karl. Die hegelsche Linke. Stuttgart: Friedrich Frommann Verlag, 1962, p. 47-62. Trad. ing.: The Recent Philosophers. In: The young hegelians, an anthology. Cambridge: Cambridge University Press, 1983, p. 359-76.

HOBBES, Thomas. Leviathan. In: Great Books, v. 23. Chicago: Britannica, 1952, p. 39283.

LOCKE, John. Segundo tratado sobre o governo. Col. Os Pensadores. São Paulo: Abril Cultural, 1978.

LYOTARD, Jean-François. “Derives”. In: Dérive à partir de Marx et Freud. Paris: UGE, 1973, col. 10/18.

19 Cf. J-F Lyotard, "Derives", p.14-15.

\begin{tabular}{|l|l|l|l|l|}
\hline Qevista Qialectus & Ano 5 & n. 12 & Janeiro - Julho 2018 & p. 163-208 \\
\hline
\end{tabular}


MARX, Karl. Manuscrits de 1844 (Manuscritos Econômicos e Filosóficos). Paris: Éditions Sociales, 1972.

MARX, Karl, e ENGELS, Friedrich. Die deutsche Ideologie. Marx \& Engels Werke, v. 3. Berlim: Dietz Verleg, 1958. Trad. francesa L'Ideologie allemande. Paris: Editions Sociales, 1968.

MARX, Karl, e ENGELS, Friedrich. La sainte famille. Paris: Éditions Sociales, 1972.

NAVILLE, Pierre. De l'aliénation à la jouissance. Paris: Éditions Anthropos, 1974.

NIETZSCHE, FRIEDRICH. La gaia scienza. Roma: Editora Riuniti, 1983.

ROSSI, Mario. Da Hegel a Marx - IV: La concezione materialistica della storia. Roma: Feltrinelli, 1975

ROUSSEAU, Jean-Jacques. Du contrat social. Paris: Editions Sociales, 1971.

ROUSSEAU, Jean-Jacques. Projeto de constituição para a Córsega. In: Obras, v. II. Porto Alegre: Editora Globo, 1962, p. 191-253.

STIRNER, Max. Der Einzige und sein Eigentum. Stuttgart, Philip Reclam, 1972. Trad. 208 francesa: L'Unique et sa proprieté, trad. de Robert Réclaire. Paris: Stock et Plus, 1978.

STIRNER, Max. "Rezensenten Stirners" ou "L'Anticritique". Edição bilingue. Paris: Aubier Montagne, 1974, p. 41-77.

THOMAS, Paul. Marx and the Anarchists. Londres: Routledge and Kegan Paul, 1980.

\begin{tabular}{|l|l|l|l|l|}
\hline Gevista Dialectus & Ano 5 & n. 12 & Janeiro - Julho 2018 & p. 163-208 \\
\hline
\end{tabular}

